\title{
Management of traumatic meniscus tears: the 2019 ESSKA meniscus consensus
}

\author{
Sebastian Kopf ${ }^{1}$ (1) - Philippe Beaufils ${ }^{2} \cdot$ Michael T. Hirschmann $^{3} \cdot$ Niccolò Rotigliano $^{3} \cdot$ Matthieu Ollivier $^{4}$. \\ Helder Pereira ${ }^{5} \cdot$ Rene Verdonk $^{6} \cdot$ Nikica Darabos $^{7} \cdot$ Panagiotis Ntagiopoulos $^{8} \cdot$ David Dejour $^{9} \cdot$ Romain Seil $^{10,11}$. \\ Roland Becker ${ }^{12}$
}

Received: 31 October 2019 / Accepted: 3 January 2020 / Published online: 13 February 2020

(c) The Author(s) 2020

\begin{abstract}
Purpose The importance of meniscus integrity in the prevention of early osteoarthritis is well known, and preservation is accepted as the primary goal. The purpose of the ESSKA (European Society for Sports Traumatology, Knee Surgery and Arthroscopy) European consensus on traumatic meniscus tears was to provide recommendations for the treatment of meniscus tears based on both scientific evidence and the clinical experience of knee experts.

Methods Three groups of surgeons and scientists elaborated and ratified the so-called formal consensus process to define the recommendations for the management of traumatic meniscus tears. A traumatic meniscus tear was defined as a tear with an acute onset of symptoms caused by a sufficient trauma. The expert groups included a steering group of eight European surgeons and scientists, a rating group of another nineteen European surgeons, and a peer review group. The steering group prepared twenty-seven question and answer sets based on the scientific literature. The quality of the answers received grades of A (a high level of scientific support), B (scientific presumption), C (a low level of scientific support) or D (expert opinion). These question and answer sets were then submitted to and evaluated by the rating group. All answers were scored from 1 (=totally inappropriate) to 9 (=totally appropriate) points. Thereafter, the comments of the members of the rating group were incorporated by the steering group and the consensus was submitted to the rating group a second time. Once a general consensus was reached between the steering and rating groups, the finalized question and answer sets were submitted for final review by the peer review group composed of representatives of the ESSKA-affiliated national societies. Eighteen representatives replied.

Results The review of the literature revealed a rather low scientific quality of studies examining the treatment of traumatic meniscus tears. Of the 27 questions, only one question received a grade of A (a high level of scientific support), and another received a grade of $\mathrm{B}$ (scientific presumption). The remaining questions received grades of $\mathrm{C}$ and $\mathrm{D}$. The mean rating of all questions by the rating group was 8.2 (95\% confidence interval 8.1-8.4). A general agreement that MRI should be performed on a systematic basis was not achieved. However, MRI was recommended when arthroscopy would be considered to identify concomitant pathologies. In this case, the indication for MRI should be determined by a musculoskeletal specialist. Based on our data, stable left in situ lateral meniscus tears appear to show a better prognosis than medial tears. When repair is required, surgery should be performed as early as possible. Evidence that biological enhancement such as needling or the application of platelet-rich plasma would improve healing was not identified. Preservation of the meniscus should be considered as the first line of treatment because of an inferior clinical and radiological long-term outcome after partial meniscectomy compared to meniscus repair.

Discussion The consensus was generated to present the best possible recommendations for the treatment of traumatic meniscus tears and provides some groundwork for a clinical decision-making process regarding the treatment of meniscus tears. Preservation of the meniscus should be the first line of treatment when possible, because the clinical and radiological long-term outcomes are worse after partial meniscectomy than after meniscus preservation. The consensus clearly states that numerous meniscus tears that were considered irreparable should be repaired, e.g., older tears, tears in obese patients, long tears, etc.

Level of evidence II
\end{abstract}

Extended author information available on the last page of the article 
Keywords Meniscus $\cdot$ Traumatic tear $\cdot$ Repair $\cdot$ Management $\cdot$ Consensus $\cdot$ Meniscus preservation

\section{Introduction}

The nomenclature of traumatic and degenerative chronic meniscus injuries should be distinguished based on their etiology. The ESSKA European meniscus consensus group defined traumatic meniscus injury as a 'meniscus tear', which is associated with a sufficient knee injury and a sudden onset of knee pain, whereas a 'meniscus lesion' is a degenerative meniscus tear marked by a slow progression of tissue degeneration without a history of an acute trauma [1]. The main types of meniscus tears are vertical tears, such as longitudinal (including bucket handle) and radial tears [2] (including flap), and posterolateral root tears. Although debate exists regarding whether tears of the meniscus ramp should also be included under the purview of traumatic meniscus tears, they are generally accepted to occur at a ligamentous connection between the posterior horn of the medial meniscus and the tibial plateau. These meniscal ramp tears often do not affect the actual meniscus tissue and thus were not counted as true meniscus tears in this consensus. In contrast, horizontal lesions are not considered traumatic meniscus tears because of their rather degenerative nature, even if they occur in younger patients [3-5]. These lesions are caused by repetitive microtrauma and degeneration of the tissue in conjunction with or without osteoarthritis (OA). The two pathologies, traumatic and degenerative, must be distinguished because of the fundamental differences in optimal management.

Traumatic meniscus tears may occur in isolation but are commonly detected in conjunction with ligament injuries. The odds ratios of developing OA after isolated meniscus injuries or combined injuries of both the anterior cruciate ligament (ACL) and the meniscus are approximately 6.3 and 6.4, respectively [6]. The main surgical treatment options are arthroscopic partial meniscectomy or meniscus repair. The latter led to less OA, a higher level of activity and higher patient satisfaction in the long term in some studies [7-10]. Despite this evidence, a significant mismatch has been identified between the incidence of repairable meniscus tears and the repair rates in clinical practice. The incidence of traumatic meniscus tears in patients with a torn ACL ranged between 57 and $80 \%$ [11, 12]. Although more than $30 \%$ of meniscus tears are estimated to be suitable for repair, less than $10 \%$ are repaired $[2,13]$. For instance, in France, $1,564,461$ meniscectomies and 63,142 meniscus repairs were performed between 2005 and 2017, resulting in a repair rate of only $4 \%$ [14]. Nevertheless, repair rates appear to increase over time. In the US, an analysis by the database of the American Board of Orthopedic Surgery revealed that the percentage of meniscus repairs has increased by $37 \%$ per surgeon from 2004 to 2012, whereas the rate of meniscectomies decreased by $17 \%$ per surgeon over the same period [15].

In addition to OA, the time to return to activity or failure rates may affect the treatment decision. After partial, subtotal or even total meniscectomy, patients generally return to their normal daily activities within 2-4 weeks. In contrast, patients require significantly more time for recovery after meniscus repair. However, meniscus repairs have a greater potential for helping patients return to the same level of activity. Another frequently mentioned drawback of meniscal repairs is their higher risk of failure and thus early revision arthroscopy in the short (16.5 vs. $1.4 \%)$ and long term (20.7 vs. $3.9 \%)$ [8], both in adults and children or adolescents (repair: 18\% vs. meniscectomy: 7\%) [16]. Nevertheless, the clinical success rate of meniscus repairs substantially outweighs the failures, by $85 \%$, as shown in a recent analysis of the literature [17].

The types of meniscus tears that are suitable for repair must be identified to perform the repair and avoid unnecessary partial meniscus resections to decrease the risk of OA and allow patients return to full activity. In our opinion, the contrast of high rates of successful meniscus repairs and its superiority to partial meniscectomy regarding OA development and the return to the preoperative level of activity and the low number of performed repairs compared to meniscectomies indicates an apparent lack of understanding about the importance of meniscus repair.

Therefore, this European consensus may help in the decision-making process for the treatment of patients with traumatic meniscus tears by also considering factors such as a high BMI, age of the meniscus tears and patients and biological treatment options. Thus, this consensus will help the surgeon to improve his decision-making process and subsequently improve patient outcomes.

\section{Materials and methods}

A European meniscus consensus project was established by the European Society of Sports Traumatology, Knee Surgery and Arthroscopy (ESSKA) between 2014 and 2018, focusing on the management of traumatic meniscus tears. A traumatic meniscus tear was defined as a tear with an acute onset of symptoms caused by a sufficient trauma.

The process of this consensus project was similar to the previously published ESSKA European degenerative meniscus consensus project (Fig. 1) [1]. Three groups of 45 experienced orthopedic surgeons and scientists (steering group, $n=8$; rating group, $n=19$; and peer review group, 
Fig. 1 Flowchart of the procedure used to determine the ESSKA consensus for traumatic meniscus tears

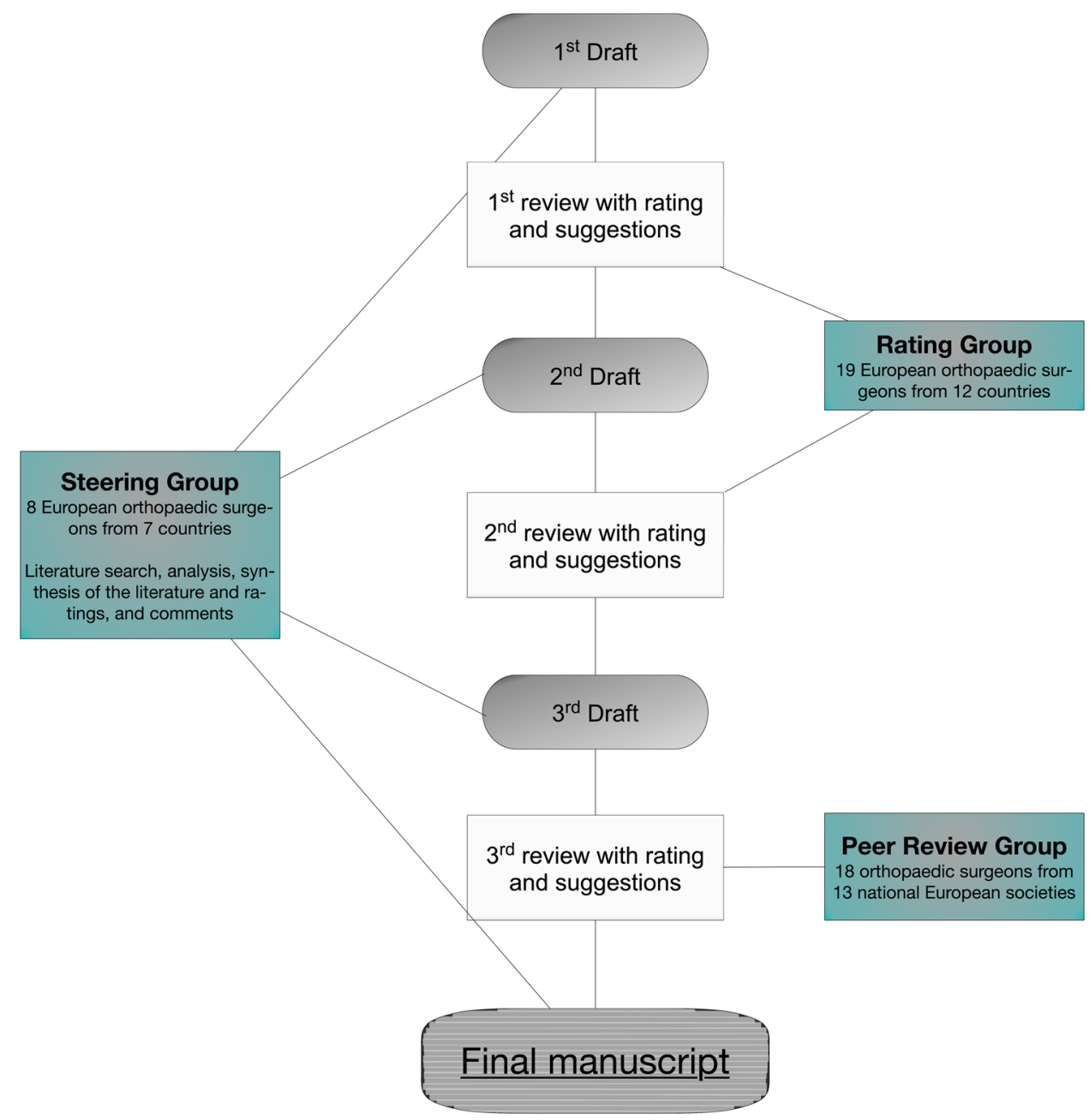

$n=18$ ) were involved in the consensus process. First, a steering group was established that included eight expert knee surgeons under the leadership of three specialists with a special interest in the management of meniscus pathologies (PB, RB, and SK). The steering group was responsible for developing the questions and answers based on an extensive review of the literature using PubMed, Embase and Cochrane Central Register of Controlled Trials. The following terms were included in the search and used in different combinations: [meniscus], [tear], [injury], [trauma], [incidence], [lesion], [location], [diagnostic], [MRI], [treatment], [management], [arthroscopy], [repair], [suture], [debridement], [anterior cruciate ligament], [demographics], [healing], [second look] and [conservative management]. Additionally, references in the identified studies were searched for relevant studies. Clinical studies with levels of evidence ranging from one to five were included in this analysis. Animal and cadaver studies were excluded. Twentyseven questions were developed according to four sections: 1. definition, 2. epidemiology, 3. diagnosis and 4. treatment. All questions were answered by the steering group based on the scientific literature. The quality of the answers was graded based on the quality of the available studies and was sorted into the appropriate grade of recommendation [18]. Grade A was defined as a high level of scientific support, grade $\mathrm{B}$ as a scientific presumption, grade $\mathrm{C}$ as a low level of scientific support, and grade D as an expert opinion. All question and answer sets were discussed and a consensus was achieved by the steering group according to the scientific grading. After a general agreement was achieved in the steering group, the questions were submitted to the rating group, which consisted of 19 European orthopedic surgeons, physiotherapists and scientists specialized in knee pathologies. Each member of the rating group was asked to score the question and answer sets according to the scientific evidence and their clinical experience on a Likert scale ranging from 1 (totally inappropriate) to 9 (totally appropriate) points. Suggestions from the participants were included after the first round. A revised draft was prepared and resubmitted to the rating group for final scoring. After the second draft was approved by both the steering and rating groups, the question and answer sets were sent to the national societies 
affiliated with ESSKA $(n=24)$. Eighteen surgeons from thirteen societies replied. The purpose of this unbiased peer review group was to evaluate the questions and answers of the manuscript after grading by the rating group to determine the feasibility, accessibility and readability of the proposed recommendations.

\section{Results}

Answers were rated with an average of 8.2 points ( $95 \%$ confidence interval 8.1-8.4). The mean points assigned by each rater ranged from 6.9 to 8.8 points. Only 1 of the 27 answers received a grade of less than 7 points (exactly 6.9), and 5 answers received scores ranging from 7 to 7.9 points.

The majority of answers, including several questions with more than one graded answer, were evaluated as grade $\mathrm{C}$ $(n=27)$ or $\mathrm{D}(n=10)$, indicating that a low level of scientific evidence is available for most of the answers. Only two answers were graded better than $\mathrm{C}$, one with a grade of $\mathrm{A}$ and another with a grade of $\mathrm{B}$. Two answers were not rated because of missing literature at the time the answers of this consensus were prepared.

\section{Questions and answers}

\section{Definition}

\section{What is the definition of a traumatic meniscus tear?}

A traumatic meniscus tear is a meniscus tear that is associated with a sufficient knee injury and a sudden onset of knee pain. Vertical tears, such as longitudinal (including bucket handle tears) and radial tears, are primarily included in this group [2]. Flap tears and mainly posterolateral root tears are also included. Tears of the meniscus ramp are also traumatic tears, but some debate persists regarding the definition. In general, they are believed to occur at a ligamentous connection between the posterior meniscus horns and the tibial plateau. They often do not affect the actual meniscus tissue and are thus not counted as true meniscus tears in this consensus. In general, horizontal lesions are not traumatic meniscus tears because of their rather degenerative nature (even in younger patients) [3-5] (Grade D).

\section{What is the definition of stable and unstable traumatic meniscus tears?}

In unstable meniscus tears, the central part of the torn meniscus can be dislocated towards the joint space to the center (horizon) of the femoral condyle, thus evoking locking and sudden pain $[19,20]$. The unstable meniscus fragment engages or is able to engage between the tibia plateau and the MCL or into the notch, or it is displaceable to at least approximately $5 \mathrm{~mm}$ [21]. A typical example is a longitudinal tear, which might temporarily evolve into a bucket handle tear. Another example might be a flap tear that engages between the femoral condyle and the tibial plateau [22-24]. In terms of partial or very short meniscus tears, a stable tear is defined as a tear that is not displaceable with the probe [25]. Radial tears are generally defined as unstable [24] (Grade D).

\section{What is the definition of a stable and unstable knee?}

Functional instability is a symptom. Laxity is a measurable sign. In the current study, a stable knee has intact ligaments. This definition also includes a stabilized knee, e.g., after ACL reconstruction, although the success of the reconstruction was not fully considered in most of the studies [26, 27] (Grade D).

\section{Which classification should be used to describe the location of a meniscus tear?}

The meniscus should be classified into circumferential and radial zones (Fig. 2) [28, 29]. The radial zones have
Fig. 2 Newly proposed classification for the localization of meniscus tears (modified scheme, originally introduced by Cooper et al. and modified by Beaufils et al. [29, 69])
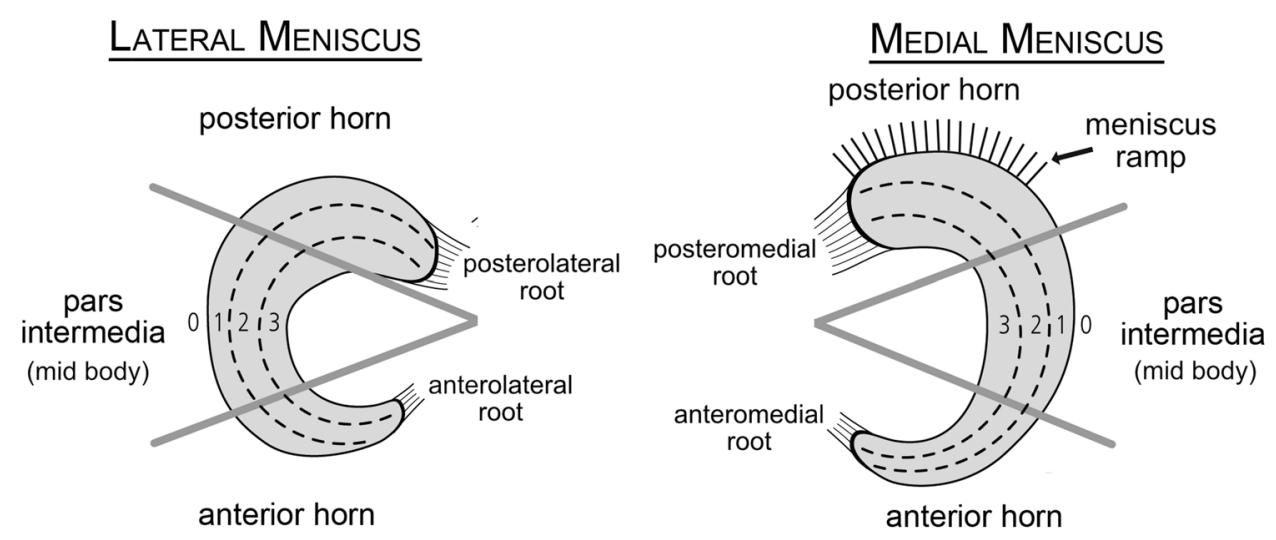
also been divided according to the vascularity in red-red, red-white, and white-white zones; however, this classification should be avoided, because vascularity changes throughout life and is often not directly assessable during surgery [30]. Furthermore, dividing the width of the meniscus into zones 0-3, as shown in Fig. 2, is a more objective and measurable approach (Grade C).

\section{Epidemiology}

\section{What is the incidence of traumatic meniscus tears in stable knees?}

For the general population, approximately $6 \%$ of acutely injured knees were reported to sustain a meniscus tear [31, 32]. The medial meniscus is involved in $75 \%$ of these cases. Numbers of acute meniscus injuries per 1000 inhabitants per year range from 0.5 to 0.7 [32,33]. Men $(0.7 / 1000$ inhabitants/year) are more frequently affected than women $(0.3 / 1000$ inhabitants/year) [33]. Approximately $15 \%$ of athletes with acute knee trauma and hemarthrosis sustain isolated meniscus tears with a higher ratio of medial (76\%) to lateral (24\%) meniscus tears [34].

Regarding isolated radial tears as a special entity of vertical meniscus tears, which are thought to mainly belong to the traumatic meniscus tears, no specific data are available for the incidence of these tears in stable knees in the literature. The rate of radial meniscus tears in patients undergoing knee arthroscopy was reported to range from 5 to $15 \%$ [2, $16,35-38]$. Unfortunately, the authors did not differentiate between stable and unstable or traumatic and degenerative tears [35, 37] (Grade C).

\section{What is the incidence of traumatic meniscus tears in unstable knees?}

(a) Acute ACL + MCL tears: In knees with combined acute tears of the ACL and the medial collateral ligament (MCL), the incidence of lateral meniscus tears is higher than medial meniscus tears $[39,40]$, where a grade III MCL lesion appears to be protective compared to a grade II MCL lesion [40]. Numbers range from 32\% for grade III MCL lesions and $71 \%$ for grade II MCL tears (Grade C).

(b) Acute ACL tears: In knees with acute tears of the ACL, the incidence of lateral meniscus tears is higher than medial meniscus tears (except ramp tears, please see below) [31, 34, 41-43]. The exact numbers vary significantly (16-82\%) [44-47]. Approximately one-third to one-quarter of the patients do not have a meniscus tear [40, 41, 44, 48] (Grade C).

(c) Chronic ACL tears: In knees with chronic tears of the ACL, meniscus tears were reported in up to $96 \%$ of the patients [45-47]. The incidence of lateral meniscus tears is lower than that of medial meniscus tears [34, 41, 49, 50]. The rate of lateral meniscus tears is not substantially affected by the time after ACL tear and age. In contrast, the rate of medial meniscus tears increases over time and with increasing age $[48,49]$ (Grade $C$ ).

\section{What is the cause of pain in traumatic meniscus tears?}

Traumatic meniscus tears themselves can cause knee pain [51, 52]. A traumatic meniscus tear can provoke pain by exerting a direct effect on the nociceptors of the meniscus and the synovial membrane $[51,53,54]$ and through elevated concentrations of intra-articular cytokines [55] (Grade C).

\section{Diagnostics}

\section{Are the clinical diagnostic tests accurate for assessing a meniscus tear of the knee?}

A combination of diagnostic tests should be used to assess the meniscus, because this approach increases the accuracy [56-62] (Grade C). Single tests only exhibit low to moderate diagnostic accuracy. A fair recommendation might be to use the McMurray joint line tenderness test because of its high sensitivity and specificity [56, 63-68] (Grade A). The Ege and Thessaly tests have also a high sensitivity and specificity, but studies using these tests are scarce [57, 63] (Table 1) (Grades $A$ and $C$ ).

\section{Is an MRI systematically necessary in a knee with a suspected traumatic meniscus tear?}

No consensus exists for this question. In addition to clinical experience, the systematic use of MRI also depends on the availability and legal issues in the different European countries. In general, MRI is a useful preoperative tool with a high accuracy for discriminating meniscus tears and other pathologies [37, 69-78]. However, if an arthroscopy is required, the usefulness of an MRI might be questioned [79-81]. It might help to improve planning of the surgery and inform the patient $[82,83]$.

The consensus group agrees that a musculoskeletal specialist should select the indication for an MRI (Grade D).

\section{Has a consensus been established for the assessment of meniscus healing?}

Several different possibilities exist to assess meniscus healing. The most reliable technique to assess meniscus healing is arthroscopy [84-88]; however, it is still a subjective examination that depends on the surgeons' skills. Magnetic resonance imaging (MRI) scans have mainly been used to 
Table 1 Sensitivity, specificity and accuracy of clinical tests to diagnose meniscal tears in different studies

\begin{tabular}{|c|c|c|c|c|c|c|c|c|c|}
\hline Study & Type of study & $\begin{array}{l}\text { Level of } \\
\text { evidence }\end{array}$ & $\begin{array}{l}\text { Number } \\
\text { of stud- } \\
\text { ies }\end{array}$ & $\begin{array}{l}\text { Number of } \\
\text { patients }\end{array}$ & Diagnostic test & $\begin{array}{l}\text { Medial/ } \\
\text { lateral } \\
\text { meniscus }\end{array}$ & $\begin{array}{l}\text { Sensi- } \\
\text { tivity } \\
{[\%]}\end{array}$ & $\begin{array}{l}\text { Speci- } \\
\text { ficity } \\
{[\%]}\end{array}$ & Accuracy [\%] \\
\hline \multirow{3}{*}{$\begin{array}{l}\text { Meserve et al. } \\
\text { [198] }\end{array}$} & \multirow{3}{*}{$\begin{array}{l}\text { Systematic } \\
\text { review }\end{array}$} & \multirow[t]{3}{*}{ I } & 8 & - & McMurray test & Both & 52 & 97 & N/A \\
\hline & & & 8 & - & $\begin{array}{l}\text { Joint line tender- } \\
\text { ness }\end{array}$ & Both & 76 & 77 & N/A \\
\hline & & & 3 & - & Appley test & Both & 22 & 88 & N/A \\
\hline \multirow{10}{*}{$\begin{array}{l}\text { Karachalios et al. } \\
{[66]}\end{array}$} & \multirow{10}{*}{$\begin{array}{l}\text { Prospective } \\
\text { cohort study }\end{array}$} & \multirow[t]{10}{*}{ I } & \multirow[t]{10}{*}{-} & \multirow{10}{*}{$\begin{array}{l}213(157 \mathrm{M} / 56 \\
\mathrm{F})\end{array}$} & \multirow[t]{2}{*}{ McMurray test } & Medial & 48 & 94 & 78 \\
\hline & & & & & & Lateral & 65 & 86 & 84 \\
\hline & & & & & \multirow{2}{*}{$\begin{array}{l}\text { Joint line tender- } \\
\text { ness }\end{array}$} & Medial & 71 & 87 & 81 \\
\hline & & & & & & Lateral & 78 & 90 & 89 \\
\hline & & & & & \multirow[t]{2}{*}{ Apley test } & Medial & 41 & 93 & 75 \\
\hline & & & & & & Lateral & 41 & 86 & 82 \\
\hline & & & & & \multirow{2}{*}{$\begin{array}{l}\text { Thessaly } 5^{\circ} \text { of } \\
\text { flexion }\end{array}$} & Medial & 66 & 96 & 86 \\
\hline & & & & & & Lateral & 81 & 91 & 90 \\
\hline & & & & & \multirow{2}{*}{$\begin{array}{l}\text { Thessaly } 20^{\circ} \text { of } \\
\text { flexion }\end{array}$} & Medial & 89 & 97 & 94 \\
\hline & & & & & & Lateral & 92 & 96 & 96 \\
\hline \multirow[t]{2}{*}{ Eren [65] } & \multirow{2}{*}{$\begin{array}{l}\text { Prospective } \\
\text { Cohort study }\end{array}$} & \multirow[t]{2}{*}{ III } & \multirow[t]{2}{*}{-} & \multirow[t]{2}{*}{104 (104 M) } & \multirow{2}{*}{$\begin{array}{l}\text { Joint line tender- } \\
\text { ness }\end{array}$} & Medial & 86 & 67 & 74 \\
\hline & & & & & & Lateral & 92 & 97 & 96 \\
\hline \multirow{2}{*}{$\begin{array}{l}\text { Jackson et al. } \\
\text { [197] }\end{array}$} & \multirow{2}{*}{$\begin{array}{l}\text { Systematic } \\
\text { review }\end{array}$} & \multirow[t]{2}{*}{ III } & \multirow[t]{2}{*}{4} & - & McMurray test & Both & 52 & 97 & N/A \\
\hline & & & & & $\begin{array}{l}\text { Joint line tender- } \\
\text { ness }\end{array}$ & Both & 76 & 29 & N/A \\
\hline Evans et al. [196] & $\begin{array}{l}\text { Prospective } \\
\text { cohort study }\end{array}$ & I & - & 164 & McMurray test & Both & 16 & 98 & N/A \\
\hline Akseki et al. [63] & Prospective & II & - & $150(110 \mathrm{M} / 40 \mathrm{~F})$ & McMurray test & Medial & 67 & 69 & 66 \\
\hline & cohort study & & & & & Lateral & 53 & 88 & 82 \\
\hline & & & & & Joint line tender- & Medial & 88 & 44 & 71 \\
\hline & & & & & ness & Lateral & 67 & 80 & 77 \\
\hline & & & & & Ege test & Medial & 67 & 81 & 71 \\
\hline & & & & & & Lateral & 64 & 90 & 84 \\
\hline Konan et al. [67] & Prospective & III & - & $109(80 \mathrm{M} / 29 \mathrm{~F})$ & McMurray Test & Medial & 50 & 77 & 57 \\
\hline & cohort study & & & & & Lateral & 21 & 94 & 77 \\
\hline & & & & & Joint Line Ten- & Medial & 83 & 76 & 81 \\
\hline & & & & & derness & Lateral & 68 & 97 & 90 \\
\hline & & & & & Thessaly $5^{\circ}$ of & Medial & 68 & 77 & 49 \\
\hline & & & & & flexion & Lateral & 89 & 30 & 71 \\
\hline & & & & & Thessaly $20^{\circ}$ of & Medial & 59 & 67 & 61 \\
\hline & & & & & flexion & Lateral & 44 & 86 & 80 \\
\hline & & & & & McMurray + & Medial & 91 & 91 & N/A \\
\hline & & & & & Joint Line & Lateral & 75 & 99 & N/A \\
\hline & & & & & Joint Line + & Medial & 93 & 92 & N/A \\
\hline & & & & & Thessaly & Lateral & 78 & 99 & N/A \\
\hline Fowler and & Prospective & I & - & $161(106 \mathrm{M} / 55 \mathrm{~F})$ & McMurray Test & Both & 29 & 95 & N/A \\
\hline Lubliner [195] & cohort study & & & & $\begin{array}{l}\text { Joint Line Ten- } \\
\text { derness }\end{array}$ & Both & 85 & 30 & N/A \\
\hline & & & & & Apley Test & Both & 16 & 80 & N/A \\
\hline Kurosaka et al. & Prospective & III & - & $156(83 \mathrm{M} / 73 \mathrm{~F})$ & McMurray Test & Both & 37 & 77 & 45 \\
\hline$[68]$ & cohort study & & & & $\begin{array}{l}\text { Joint Line Ten- } \\
\text { derness }\end{array}$ & Both & 55 & 67 & 57 \\
\hline & & & & & Apley Test & Both & 13 & 90 & 28 \\
\hline
\end{tabular}


Table 1 (continued)

\begin{tabular}{|c|c|c|c|c|c|c|c|c|c|}
\hline Study & Type of study & $\begin{array}{l}\text { Level of } \\
\text { evidence }\end{array}$ & $\begin{array}{l}\text { Number } \\
\text { of stud- } \\
\text { ies }\end{array}$ & $\begin{array}{l}\text { Number of } \\
\text { patients }\end{array}$ & Diagnostic test & $\begin{array}{l}\text { Medial/ } \\
\text { lateral } \\
\text { meniscus }\end{array}$ & $\begin{array}{l}\text { Sensi- } \\
\text { tivity } \\
{[\%]}\end{array}$ & $\begin{array}{l}\text { Speci- } \\
\text { ficity } \\
{[\%]}\end{array}$ & Accuracy [\%] \\
\hline \multirow[t]{10}{*}{ Gobbo et al. [56] } & \multirow{10}{*}{$\begin{array}{l}\text { Prospective } \\
\text { cross-sectional } \\
\text { study }\end{array}$} & \multirow[t]{10}{*}{ III } & \multirow[t]{10}{*}{-} & \multirow[t]{10}{*}{$162(117 \mathrm{M} / 45 \mathrm{~F})$} & \multirow[t]{2}{*}{ McMurray Test } & Medial & 65 & 58 & 61 \\
\hline & & & & & & Lateral & 62 & 49 & 52 \\
\hline & & & & & \multirow[t]{2}{*}{ Apley Test } & Medial & 50 & 65 & 57 \\
\hline & & & & & & Lateral & 50 & 60 & 57 \\
\hline & & & & & \multirow[t]{2}{*}{ Steinmann I Test } & Medial & 70 & 56 & 63 \\
\hline & & & & & & Lateral & 59 & 44 & 48 \\
\hline & & & & & \multirow{2}{*}{$\begin{array}{l}\text { Steinmann II } \\
\text { Test }\end{array}$} & Medial & 68 & 56 & 62 \\
\hline & & & & & & Lateral & 59 & 45 & 49 \\
\hline & & & & & \multirow[t]{2}{*}{ All tests together } & Medial & 89 & 31 & 60 \\
\hline & & & & & & Lateral & 86 & 24 & 40 \\
\hline \multirow[t]{2}{*}{ Corea et al. [194] } & \multirow{2}{*}{$\begin{array}{l}\text { Prospective } \\
\text { cohort study }\end{array}$} & \multirow[t]{2}{*}{ II } & \multirow[t]{2}{*}{-} & \multirow[t]{2}{*}{93} & \multirow[t]{2}{*}{ McMurray Test } & Medial & 65 & 93 & N/A \\
\hline & & & & & & Lateral & 52 & 94 & N/A \\
\hline \multirow{2}{*}{$\begin{array}{l}\text { Solomon et al. } \\
\text { [193] }\end{array}$} & \multirow{2}{*}{$\begin{array}{l}\text { Systematic } \\
\text { review }\end{array}$} & \multirow[t]{2}{*}{ III } & \multirow[t]{2}{*}{4} & \multirow[t]{2}{*}{-} & McMurray & Both & 53 & 59 & N/A \\
\hline & & & & & $\begin{array}{l}\text { Joint Line Ten- } \\
\text { derness }\end{array}$ & Both & 79 & 15 & N/A \\
\hline
\end{tabular}

$M$ male, $F$ female

evaluate meniscus healing, but signal changes persist for a long time and often do not correlate with clinical symptoms [86, 89-91]. Changes in MRI may occur even in asymptomatic knees. Thus, when the healing status is uncertain, magnetic resonance arthrography (MRA) might be a better choice than blank MRI [92-94]. Researchers have not determined whether direct (= intraarticular) or indirect (=intravenous) MRA should be used [94]. In the case of contraindications, arthro-computed tomography (CT) is a good alternative [91, 95], but it uses radiation. Both MRI and CT scans have the advantage that they are able to be assessed by different physicians as can clear arthroscopic pictures (Grade B).

\section{Factors affecting the success rate of repaired traumatic meniscus tears}

11.1 Does the location of a traumatic meniscus tear (zones 0-3) play a role in successful repair? Yes, the location of a traumatic meniscus tear plays a role in the failure rate after repair. Repaired tears in Cooper zones 1 and 2 lead to excellent and good clinical mid-term results (from 64 to $91 \%$ ) [96-100]. However, tears located in zone 1 have a statistically significantly better healing rate (from 87 to $91 \%$ ) than tears located in zone 2 (from 59 to $79 \%$ ) [84, 101, 102].

Furthermore, some studies have reported good clinical outcomes (from 75 to $87 \%$ ) in selected patients with tears located in zone 3 [103-106] or have reported no correlation between the location of the tear and the results [107]. Thus, we concluded that the location of the tear in this zone should not be considered as an absolute contraindication for meniscus repair (Grade C).

11.2 Does the location of the traumatic meniscus tear (anterior or posterior horn or pars intermedia) play a role in successful repair? The anterior-to-posterior location of a traumatic meniscus tear does not appear to affect the surgical outcome [107]. However, the literature is very scarce (Grade C).

11.3 Does the length of a repaired longitudinal traumatic meniscus tear play a role in successful repair? The literature is controversial regarding whether the length of a longitudinal meniscus tear affects the success of a repair [84, 86, 107-120]. Thus, the length of the meniscus tear should not be a contraindication for repair or partial meniscectomy (Grade C).

11.4 Does the patient's age affect the success of the meniscus repair? The patient's age does not appear to affect the failure rate of repairs of traumatic meniscus tears (available studies included patients with ages ranging from 9 to 58 years). However, the degeneration of the meniscus tissue in older patients should be considered [84, 85, 96, 99-103, 121, 122] (Grade C). 
11.5 Does the patient's BMI or weight affect the success of meniscus repair? Although a higher BMI increases the likelihood of a degenerative meniscus lesion [123-125], patients with a higher BMI (up to 35) do not appear to have a higher risk for failure of meniscus repairs [126] (Grade C).

11.6 Does the patient's level of activity affect the success of meniscus repair? Controversial results were reported in the literature regarding the correlation between patients' activity after meniscus repair and its success or failure [21, 96, 127-129]. Thus, no recommendation can be provide whether patients should go back to their preinjury activity level (Grade $C$ ).

11.7 Does lower limb alignment affect the success of repaired traumatic meniscus tears? In contrast to the case for degenerative meniscus lesions, a clear relationship has not been observed between joint alignment and the recommended treatment for a traumatic meniscus tear. No particular studies have investigated the question of whether a traumatic meniscus tear in a varus or valgus knee should be treated differently compared to a straight knee (Grade D).

\section{What is the fate of traumatic meniscus tears left in situ?}

No results are available regarding the self-healing potential of isolated meniscus tears to our knowledge.

Meniscus tears left in situ at the time of ACL reconstruction have a low rate of reoperation (from 0 to $30 \%$ ). Lateral meniscus tears appear to have a better prognosis in terms of secondary partial meniscectomy than medial meniscus tears left in situ (79-100\% vs. 63-100\%, respectively) [19, 24, 107, 114, 130-143].

Notably, most studies examined stable meniscus tears left in situ without treatment $[24,25,114,118,135,138$, 140-144]. Nevertheless, Shelbourne and Heinrich included eight unstable meniscus tears in their study. None of the patients required a subsequent surgery [139]. One must also consider that some studies did not repair or partially resect the meniscus tear, but instead performed 'biological' treatments, such as rasping or needling.

Divergent results were identified in the literature regarding the correlation between tear length and failure rate of tears left in situ. Some studies reported a statistically significant higher rate of reoperations when the tear was longer than $10 \mathrm{~mm}[131,135]$. However, other studies did not observe a significant correlation [107, 140] or did not consider the length of the tear as a criterion [138, 142, 145] (Grade C).

Thus, in general, small tears $(\leq 10 \mathrm{~mm})$ of the lateral meniscus can be left alone and do not require repair or partial meniscectomy. Tears of the medial meniscus should be repaired (Grade D).
13. What are the indications for the different treatment options for longitudinal traumatic meniscus tears in stable knees?

Preservation of the meniscus is the first-line option because the clinical and radiological long-term outcomes are worse after partial meniscectomy than meniscus repair $[8,9,69$, 146-149].

In general, traumatic meniscus tears are treated with repair, left in situ, or partial meniscectomy. Repair and left in situ are the most favorable treatment options, whereas the latter option is recommended for stable tears of the lateral meniscus during ACL reconstructions (see question 9) $[8,9,24,69,84,103,106,121,132,135,138,140,143$, 145-147, 149, 150]. Thus, repair is recommended for medial meniscus tears, unstable tears, such as bucket handle and double longitudinal tears, and isolated meniscus tears [84, 103, 106, 146].

To date, repair and left in situ repairs have not been compared directly, but the healing rates for tears of the lateral meniscus during ACL reconstruction appear to be comparable for all three meniscus zones (zones 3 to 1) (Grade C).

Partial meniscectomy of traumatic meniscus tears should only be applied if the other two treatment options are not applicable, e.g., in complex tears, tears with a high degree of degeneration, flap tears or nonreducible bucket handle tears (Grade D).

\section{What are the indications for the different treatment options for radial traumatic meniscus tears (except root tears) in stable knees?}

(a) Complete radial tears may exert a detrimental effect on the knee, because they potentially represent an almost complete loss of meniscus function. In general, traumatic radial meniscus tears are treated with repair, left in situ or partial meniscectomy. Radial tears of zones 1 and 2 should be repaired to restore the integrity of the rim in patients with or without concomitant ACL reconstruction [69, 103, 106, 149, 151-153]. Only when the tear is technically not repairable or a retear of a failed repair occurs should partial meniscectomy be considered. Partial meniscectomy should not be the first-line treatment for tears of zone 1 and 2, because of its worse long-term outcome than repaired tears [8, 69, 149] (Grade C).

(b) Nontreatment of the radial tear was also described as a treatment option for stable tears in all three zones (1-3) during concomitant ACL reconstruction [24, 69, 132, 135, $139,145,149]$. Despite the good clinical results, the healing rates of repeated arthroscopic surgeries were very low, and these studies were only mid-term follow-up studies. Thus, this treatment approach is not recommended (Grade D). 
(c) In contrast, radial tears of zone 3 can be treated with a partial meniscectomy that preserves the peripheral wall. Some surgeons also prefer to repair the torn part of zones 1 and 2 and perform a partial resection of zone 3 . However, no research studies compared this combined treatment with the repair of all three zones (Grade D).

\section{Should posterolateral meniscus root tears be repaired?}

Posterolateral meniscus root tears (PLMRT) are mainly traumatic injuries that frequently occur with ACL tears. These root tears should be repaired, particularly if the meniscofemoral ligament does not exist or is injured [84, 154]. The repair of PLMRT decreases meniscus extrusion (in the sagittal plane) and the risk of OA compared to untreated tears in patients with concomitant ACL reconstruction. However, no differences were observed in Lysholm scores and objective IKDC grading between treated and untreated PLMRT [155, 156] (Grade C).

\section{Should a posteromedial meniscus root tear be repaired?}

Medial meniscus roots tears may be traumatic; however, they generally present a degenerative nature. Root repair is typically recommended because it results in a better clinical outcome than conservative treatment and partial meniscectomy $[157,158]$ and may also reduce the risk of progression of OA. The degree of OA plays an important role in determining the outcome: the higher the degree of OA, the less favorable the results (Grade $C$ ).

\section{What is the optimal timing of a successful repair of stable and unstable meniscus tears?}

A repair that is completed as early as possible appears to produce a better clinical outcome, including a decreased failure rate (Table 2). In general, acutely repaired meniscus tears achieve superior results compared to chronically repaired tears (Table 2). However, repaired chronic meniscus tears achieve good to excellent results and thus should be repaired, when indicated, instead of partially resected (Table 2) (Grade C).

\section{What is the best method to treat an acute, nonreducible (= locked) bucket handle meniscus tear in combination with an ACL tear in the office or emergency room?}

(a) Chronic ACL tear: In a noninflammatory knee with an ACL injury that occurred several weeks or more ago and an acute, nonreducible bucket handle meniscus tear, the preferred treatment is the prompt repair of the meniscus and the simultaneous reconstruction of the ACL [159, 160]. The group does not recommend a two-stage treatment with an initial repair of the meniscus tear and secondary reconstruction of the ACL, as proposed by other researchers [105, 161] (Grade $C$ ).

(b) Acute ACL tear: Similarly, in an acutely injured knee with an ACL tear and a nonreducible bucket handle meniscus tear, the preferred treatment is the prompt repair of the meniscus and the possible reconstruction of the ACL in the same procedure. One study recommended a concomitant ACL reconstruction and meniscus repair if it was able to be

Table 2 Success rates of meniscus repairs depending on time of repair after tear

\begin{tabular}{|c|c|c|c|c|c|c|c|}
\hline Study & Type of study & $\begin{array}{l}\text { Level of } \\
\text { evidence }\end{array}$ & Number of patients & Treatment & Time cutoff & Acute/chronic & $\begin{array}{l}\text { Success } \\
\text { rate [\%] }\end{array}$ \\
\hline Steenbrugge et al. (2002) & Prospective study & IV & $13(7 \mathrm{M} / 6 \mathrm{~F})$ & Meniscal repair & 2 weeks & $\begin{array}{l}\text { Acute } \\
\text { Chronic }\end{array}$ & $\begin{array}{r}100 \\
80\end{array}$ \\
\hline Stone et al. [100] & Prospective study & IV & 31 & Meniscal repair & 2 weeks & $\begin{array}{l}\text { Acute } \\
\text { Chronic }\end{array}$ & $\begin{array}{r}100 \\
64\end{array}$ \\
\hline Cannon and Vittori [111] & Prospective study & IV & 90 & Meniscal repair & 8 weeks & $\begin{array}{l}\text { Acute } \\
\text { Chronic }\end{array}$ & $\begin{array}{l}88 \\
79\end{array}$ \\
\hline Buseck and Noyes & Prospective study & IV & $66(21 \mathrm{M} / 45 \mathrm{~F})$ & Meniscal repair & 8 weeks & $\begin{array}{l}\text { Acute } \\
\text { Chronic }\end{array}$ & $\begin{array}{l}97 \\
90\end{array}$ \\
\hline Barrett et al. [121] & Prospective study & IV & $37(26 \mathrm{M} / 11 \mathrm{~F})$ & Meniscal repair & 8 weeks & $\begin{array}{l}\text { Acute } \\
\text { Chronic }\end{array}$ & $\begin{array}{l}89 \\
78\end{array}$ \\
\hline Eggli et al. (1995) & Prospective study & IV & 54 & Meniscal repair & 8 weeks & $\begin{array}{l}\text { Acute } \\
\text { Chronic }\end{array}$ & $\begin{array}{l}90 \\
71\end{array}$ \\
\hline Noyes et al. (2000) & Prospective study & IV & 27 & Meniscal repair & 10 weeks & $\begin{array}{l}\text { Acute } \\
\text { Chronic }\end{array}$ & $\begin{array}{l}90 \\
85\end{array}$ \\
\hline Venkatachalam et al. (2001) & Prospective study & IV & $59(38 \mathrm{M} / 21 \mathrm{~F})$ & Meniscal repair & 3 months & $\begin{array}{l}\text { Acute } \\
\text { Chronic }\end{array}$ & $\begin{array}{l}92 \\
58\end{array}$ \\
\hline
\end{tabular}


completed within approximately $60 \mathrm{~h}$ after the injury [162]. An increase in the arthrofibrosis rate was not reported when patients received ACL reconstruction within the first $60 \mathrm{~h}$ compared to delayed surgery (Grade C).

(c) Subacute ACL tear (inflamed knee): Controversy exists regarding the procedure for treating subacute cases with a ACL tear that occurred several days prior to surgery and a clinically nonreducible bucket handle meniscus tear in an inflamed knee (= knee irritation, effusion, swelling) [163]. The first treatment option is the repair of the bucket handle meniscus tear and the reconstruction of the ACL (one-stage surgery), which poses a risk of arthrofibrosis but protects the repaired meniscus [164]. Alternatively, a two-stage approach can be chosen in which the meniscus tear is repaired first, followed by the reconstruction of the ACL. ACL reconstruction can be performed after full ROM is attained and the knee is no longer inflamed [105]. This approach would also offer the patient time to heal between the two surgeries, to prepare for the ACL reconstruction, and to assess the meniscus healing during the second surgery [161]. The ACL reconstruction should not be delayed too long because the risk of meniscus (re-) tear increases by $1 \%$ with each 1-month interval from injury to surgery [165, 166]. Because repaired menisci do not perform well in ACLdeficient knees, and a new meniscus tear may develop in these knees, patients may wear a brace between the surgeries to potentially protect the menisci [165-167]. One-stage and two-stage approaches were not compared in the literature in subacute patients with inflamed knees. These approaches were only compared in chronic patients and produced controversial results $[105,159]$. Therefore, the prompt repair of the meniscus is recommended, but no recommendation is proposed regarding whether the ACL should be reconstructed simultaneously or after inflammation is resolved and full range of motion (ROM) is attained (Grade D).

\section{What are the indications for partial meniscus substitution?}

(a) The implantation of partial meniscus replacements (PMR) of the medial meniscus during the first partial (subtotal) resection is a topic of discussion, as the only level-1 study showed no benefit of PMR compared to isolated partial meniscectomy $[168,169]$. Thus, the implantation of a PMR within the first surgery for partial meniscectomy is not generally recommended. Partial meniscus replacement may be considered for patients with failed meniscus surgeries and meniscus-related complaints [168, 170-172]. (Grade A).

(b) Results for lateral and medial PMR are similar, according to one study [173] (Grade C).

(c) According to one study, the implantation of a PMR (collagen meniscus implant $=\mathrm{CMI}$ ) in combination with ACL reconstruction produced a superior outcome in the first surgery compared to a partial meniscectomy alone [174]. However, these results should be interpreted with caution, because it was retrospective study that included a heterogeneous group of patients (Grade C).

\section{Are biological techniques useful to enhance meniscus healing?}

A. Does RASPING of a meniscus tear and/or the surrounding synovial membrane enhance meniscus healing?

Although rasping is an easy, cheap and quickly performed technique, researchers have not clearly determined whether rasping is appropriate to enhance meniscus healing. Studies evaluating patients with isolated meniscus tears are lacking. Only a few studies are available that included patients with concomitant ACL rupture. These studies reported controversial results regarding meniscus rasping $[19,175]$. Concomitant ACL reconstruction positively affects meniscus healing; thus, it is a severe confounder in the aforementioned studies [111, 176-178] (Grade C).

B. Does NEEDLING of the meniscus tear enhance the healing of a meniscus tear?

Studies on the needling of isolated full-thickness traumatic meniscus tears are lacking $[179,180]$. Thus, no evidence reported to date supports the use of this treatment, and surgeons should apply it with caution. In the case of using needling of a meniscus to enhance healing, the surgeon must carefully consider the potential of the needle used in this technique to damage the meniscus [181] (Grade C).

C. Does OPENING THE MEDULlARY CAVITY enhance meniscus healing?

Clinical studies of the ability of this method to enhance meniscus healing in patients with isolated meniscus repairs are lacking. Thus, no statement can be made. Grade: n/a.

D. Does the local application of FIBRIN GLUE enhance meniscus healing?

Studies evaluating patients with isolated (without concomitant ACL reconstruction) meniscus repair performed with fibrin glue are lacking. Only two studies published by the same study group have evaluated the effect of locally applied fibrin glue into repaired meniscus tears [182, 183]. Nevertheless, both studies included several patients with concomitant ACL reconstruction. Concomitant ACL reconstruction positively affects meniscus healing [111, 176-178]. Thus, the use of locally applied fibrin glue to enhance meniscus healing may be considered, but is not currently recommended (Grade C).

E. Does the local application of a FIBRIN CLOT enhance meniscus healing?

In general, the use of an isolated fibrin clot is not recommended for the treatment of traumatic full-thickness meniscus tears due to a lack of studies. For radial tears, weak evidence of a positive effect of fibrin clots that have been 
locally applied into meniscus tears exists, based on promising results from a small case series [152, 184] (Grade C).

F. Does the local application of PLATELET-RICH PLASMA (PRP) enhance meniscus healing?

The additional use of PRP during the repair of traumatic meniscus tears is not recommended. The only available study did not show an improvement when using PRP compared to isolated meniscus repairs [185]. (Grade C).

G. Does the LOCAL APPLICATION OF CELLS enhance the healing of a meniscus tear?

The local application of cells to enhance meniscus healing is not recommended, because no published studies have evaluated the isolated effects of cells on meniscus healing (with or without sutures) Grade: n/a.

\section{Discussion}

The main message of this consensus is that the preservation of the meniscus should be the first choice of treatment for traumatic meniscus tears, because of its excellent outcome in terms of the return to a high level of activity and OA prevention, as evidenced by the agreement between the literature and expert opinion. The preservation of the meniscus is of utmost importance because menisci play important roles in load distribution, joint stabilization, neuromuscular function, lubrication and cartilage nutrition [186-188]. Approximately $30 \%$ of meniscus tears are potentially repairable, and only up to $10 \%$ are currently repaired [13]. The main reasons for this gap appear to be faster recovery after meniscectomy, lower costs of the surgical procedure and the risk of revision surgery [189]. Several factors are considered responsible for higher failure rates, such as an older age of patients, high BMI, chronicity of tears, tear length or tear location in Cooper zone 3. In this consensus, none of these factors were contraindications for meniscus repair. In particular, repair should be performed for longitudinal tears with a length greater than $10 \mathrm{~mm}$, including bucket handle tears, radial tears of Cooper zones 1 and 2, and root tears. This recommendation also includes late repairs, if technically reasonable, because healing rates are still very good, even for late repairs. These tears frequently cause a complete loss of meniscus function. Early repair may produce a better outcome than delayed repair. Thus, although patients rapidly return to work and sports after partial meniscectomy, the costs of initial surgery are lower and the failure rate is lower than meniscus repairs, the significant inferior longterm outcomes of patients with partially resected menisci compared to repairs in terms of OA and the return to a high activity level highlight the value of repairing meniscus tears $[7,9,190]$.

Meniscus tears rarely occur in isolation and are often associated with anterior cruciate ligament (ACL) injuries.
Ideally, both pathologies are addressed during the same surgery. Isolated meniscus repairs in unstable knees, such as an ACL-deficient knee, should be avoided because of their high failure rate. Additionally, meniscus repairs performed with concomitant ACL reconstruction show a higher healing rate. The explanations for this higher healing rate might be attributed to bone marrow-derived stem cells originating from ACL tunnel drilling, a more conservative rehabilitation protocol after ACL reconstruction, or the surgically induced formation of a hematoma that releases specific growth factors and stem cells. However, the concomitant treatment of meniscus and ACL tears might be a challenging decision such as during the first few days after knee injury in a patient whose knee has acute inflammation with a large effusion, a range of motion deficit and bucket handle tears, which was not reducible conservatively and thus requires surgery. In general, in the case of inflammation in the knee, knee surgery would be delayed until symptoms have disappeared. However, a bucket handle meniscus tear should be reduced and repaired as early as possible to result in the highest possibility of a successful repair and to avoid the unnecessarily prolonged suffering of the patient. Under these specific circumstances, instant ACL reconstruction may be performed concomitantly with meniscus repair, even after considering the risk of arthrofibrosis. Another option would be to reduce and repair the meniscus and to stabilize the knee with an orthosis until the inflammatory phase, including effusion, resolves and ROM is acceptable, allowing a safer ACL reconstruction.

An interesting topic that has attracted increasing attention over the last few years is the use of so-called biologicals or biological techniques to improve meniscus healing. These techniques are mainly used concomitantly with meniscus repair and include the local application of platelet-rich plasma, stem cells, blood clots, and fibrin glue. Furthermore, needling of the meniscus tissue around the tear, rasping of the meniscus tear and surrounding synovial membrane, as well as opening of the medullary cavity are also biological techniques. Interestingly, during the period of establishing the consensus, none of these techniques had been confirmed to enhance meniscus healing in humans. However, a recent study showed a positive effect of the latter technique on meniscus healing. In this study, similar healing rates were observed in patients undergoing meniscus repairs with concomitant ACL reconstruction and isolated meniscus repairs with opening of the medullary cavity [191].

In addition to the patient's history, a clinical examination is required to diagnose traumatic meniscus tears. The McMurray test shows the highest sensitivity and specificity. Nevertheless, it still has a limited accuracy. To improve the sensitivity and specificity, a special score has been introduced to improve the sensitivity and specificity that includes the following five criteria: (1) the history of 
locking and catching, (2) pain upon hyperextension and (3) hyperflexion, (4) pain when palpating the joint line and (5) a positive McMurray test. If all these criteria are met, the predictive value is $92 \%$, and the predictive value of four and three positive criteria is $82 \%$ and $77 \%$, respectively [192]. In addition to a clinical examination, MRI plays an important role in diagnosing meniscus tears. Thus, MRI should be available prior to surgery mainly for two reasons. It will help identify the type of meniscus tear, which may significantly affect the choice of the type of surgery, and it may be useful to diagnose associated pathologies. The most commonly associated pathologies are ACL injuries, which are sometimes difficult to diagnose, e.g., in patients with bucket handle tears. Interestingly, a 3 Tesla MRI does not appear to significantly improve the sensitivity and specificity in diagnosing meniscus tears compared to a 1.5 Tesla MRI if a good knee coil is used [78].

This consensus has some limitations. The scientific level of evidence of the consensus is only as good as the literature. The analysis of the literature revealed a limited number of studies with a high level of evidence available. The validation of all questions and answers by the rating and peer review groups provides important input based on the expert opinions of orthopedic surgeons with a special interest in this field. Therefore, a consensus should not be considered as a guideline for the treatment of traumatic meniscus tears, but it does provide the best recommendation possible for the treatment of traumatic meniscus tears based on the current scientific evidence and clinical expertise. Since the knowledge on this topic will continue to evolve with further studies, deeper insights could be obtained in the future.

\section{Conclusions}

The consensus was generated to present the best possible recommendations for the treatment of traumatic meniscus tears and provides some groundwork for a clinical decision-making process regarding the treatment of meniscus tears. Preservation of the meniscus should be the first line of treatment when possible because the clinical and radiological long-term outcomes are worse after partial meniscectomy than after meniscus preservation. The consensus clearly states that numerous meniscus tears that were considered irreparable should be repaired, e.g., older tears, tears in obese patients, long tears, etc.

Acknowledgements Open Access funding provided by Projekt DEAL. We sincerely thank all members of the steering, rating and peer review groups as well as the National societies that participated.

\section{Compliance with ethical standards}

Conflict of interest The authors declare that they have no conflict of interest.

Funding This study was funded by the European Society of Sports Traumatology, Knee Surgery, and Arthroscopy (ESSKA).

Ethical approval This article does not contain any studies with human participants performed by any of the authors.

Open Access This article is licensed under a Creative Commons Attribution 4.0 International License, which permits use, sharing, adaptation, distribution and reproduction in any medium or format, as long as you give appropriate credit to the original author(s) and the source, provide a link to the Creative Commons licence, and indicate if changes were made. The images or other third party material in this article are included in the article's Creative Commons licence, unless indicated otherwise in a credit line to the material. If material is not included in the article's Creative Commons licence and your intended use is not permitted by statutory regulation or exceeds the permitted use, you will need to obtain permission directly from the copyright holder. To view a copy of this licence, visit http://creativecommons.org/licenses/by/4.0/.

\section{References}

1. Beaufils P, Becker R, Kopf S, Englund M, Verdonk R, Ollivier M, Seil R (2017) Surgical management of degenerative meniscus lesions: the 2016 ESSKA meniscus consensus. Knee Surg Sports Traumatol Arthrosc 25:335-346

2. Poehling GG, Ruch DS, Chabon SJ (1990) The landscape of meniscal injuries. Clin Sports Med 9:539-549

3. Christoforakis J, Pradhan R, Sanchez-Ballester J, Hunt N, Strachan RK (2005) Is there an association between articular cartilage changes and degenerative meniscus tears? Arthroscopy 21:1366-1369

4. Smillie IS (1968) The current pattern of the pathology of meniscus tears. Proc R Soc Med 61:44-45

5. Yim JH, Seon JK, Song EK, Choi JI, Kim MC, Lee KB, Seo HY (2013) A Comparative study of meniscectomy and nonoperative treatment for degenerative horizontal tears of the medial meniscus. Am J Sports Med 41:1565-1570

6. Poulsen E, Goncalves GH, Bricca A, Roos EM, Thorlund JB, Juhl CB (2019) Knee osteoarthritis risk is increased 4-6 fold after knee injury - a systematic review and meta-analysis. Br J Sports Med 53(23):1454-1463

7. Lutz C, Dalmay F, Ehkirch FP, Cucurulo T, Laporte C, Le Henaff G, Potel JF, Pujol N, Rochcongar G, Salledechou E, Seil R, Gunepin FX, Sonnery-Cottet B, French Arthroscopy Society (2015) Meniscectomy versus meniscal repair: 10 years radiological and clinical results in vertical lesions in stable knee. Orthop Traumatol Surg Res 101:327-331

8. Paxton ES, Stock MV, Brophy RH (2011) Meniscal repair versus partial meniscectomy: a systematic review comparing reoperation rates and clinical outcomes. Arthroscopy 27:1275-1288

9. Stein T, Mehling AP, Welsch F, von Eisenhart-Rothe R, Jäger A (2010) Long-term outcome after arthroscopic meniscal repair versus arthroscopic partial meniscectomy for traumatic meniscal tears. Am J Sports Med 38:1542-1548

10. Weber J, Koch M, Angele P, Zellner J (2018) The role of meniscal repair for prevention of early onset of osteoarthritis. J Exp Orthop Germany 5:10 
11. Fetzer GB, Spindler KP, Amendola A, Andrish JT, Bergfeld JA, Dunn WR, Flanigan DC, Jones M, Kaeding CC, Marx RG, Matava MJ, McCarty EC, Parker RD, Wolcott M, Vidal A, Wolf BR, Wright RW (2009) Potential market for new meniscus repair strategies: evaluation of the MOON cohort. J Knee Surg 22:180-186

12. van der List JP, Jonkergouw A, van Noort A, Kerkhoffs GMMJ, DiFelice GS (2019) Identifying candidates for arthroscopic primary repair of the anterior cruciate ligament: a case-control study. Knee 26:619-627

13. Espejo-Reina A, Aguilera J, Espejo-Reina MJ, Espejo-Reina MP, Espejo-Baena A (2019) One-third of meniscal tears are repairable: an epidemiological study evaluating meniscal tear patterns in stable and unstable knees. Arthroscopy 35:857-863

14. Abram SGF, Judge A, Beard DJ, Wilson HA, Price AJ (2018) Temporal trends and regional variation in the rate of arthroscopic knee surgery in England: analysis of over 1.7 million procedures between 1997 and 2017. Has practice changed in response to new evidence? Br J Sports Med. https://doi.org/10.1136/bjspo rts-2018-099414

15. Parker BR, Hurwitz S, Spang J, Creighton R, Kamath G (2016) Surgical trends in the treatment of meniscal tears: analysis of data from the american board of orthopaedic surgery certification examination database. Am J Sports Med 44:1717-1723

16. Shieh A, Bastrom T, Roocroft J, Edmonds EW, Pennock AT (2013) Meniscus tear patterns in relation to skeletal immaturity: children versus adolescents. Am J Sports Med 41:2779-2783

17. Kopf S, Stärke C, Becker R (2011) Klinische Ergebnisse nach Meniskusnaht. Arthroskopie 24:30-35

18. Shekelle PG, Woolf SH, Eccles M, Grimshaw J (1999) Clinical guidelines: developing guidelines. BMJ 318:593-596

19. Uchio Y, Ochi M, Adachi N, Kawasaki K, Iwasa J (2003) Results of rasping of meniscal tears with and without anterior cruciate ligament injury as evaluated by second-look arthroscopy. Arthroscopy 19:463-469

20. Vande Berg BC, Poilvache P, Duchateau F, Lecouvet FE, Dubuc JE, Maldague B, Malghem J (2001) Lesions of the menisci of the knee: value of MR imaging criteria for recognition of unstable lesions. AJR Am J Roentgenol 176:771-776

21. Mintzer CM, Richmond JC, Taylor J (1998) Meniscal repair in the young athlete. Am J Sports Med 26:630-633

22. Fahmy NR, Williams EA, Noble J (1983) Meniscal pathology and osteoarthritis of the knee. J Bone Joint Surg Br 65:24-28

23. Newman AP, Daniels AU, Burks RT (1993) Principles and decision making in meniscal surgery. Arthroscopy 9:33-51

24. Weiss CB, Lundberg M, Hamberg P, DeHaven KE, Gillquist J (1989) Non-operative treatment of meniscal tears. J Bone Joint Surg Am 71:811-822

25. DeHaven KE, Sebastianelli WJ (1990) Open meniscus repair. Indications, technique, and results. Clin Sports Med 9:577-587

26. Pujol N, Tardy N, Boisrenoult P, Beaufils P (2015) Long-term outcomes of all-inside meniscal repair. Knee Surg Sports Traumatol Arthrosc Germany 23:219-224

27. Tucciarone A, Godente L, Fabbrini R, Garro L, Salate Santone F, Chillemi C (2012) Meniscal tear repaired with Fast-Fix sutures: clinical results in stable versus ACL-deficient knees. Arch Orthop Trauma Surg 132:349-356

28. Anderson AF, Irrgang JJ, Dunn W, Beaufils P, Cohen M, Cole BJ, Coolican M, Ferretti M, Glenn RE, Johnson R, Neyret P, Ochi M, Panarella L, Siebold R, Spindler KP, Ait Si Selmi T, Verdonk P, Verdonk R, Yasuda K, Kowalchuk DA (2011) Interobserver reliability of the international society of arthroscopy, knee surgery and orthopaedic sports medicine (ISAKOS) classification of meniscal tears. Am J Sports Med 39:926-932

29. Cooper DE, Arnoczky SP, Warren RF (1990) Arthroscopic meniscal repair. Clin Sports Med 9:589-607
30. Petersen W, Tillmann B (1995) Age-related blood and lymph supply of the knee menisci A cadaver study. Acta Orthop Scand 66:308-312

31. Maffulli N, Binfield PM, King JB, Good CJ (1993) Acute haemarthrosis of the knee in athletes. A prospective study of 106 cases. J Bone Joint Surg Br 75:945-949

32. Nielsen AB, Yde J (1991) Epidemiology of acute knee injuries: a prospective hospital investigation. J Trauma 31:1644-1648

33. Hede A, Jensen DB, Blyme P, Sonne-Holm S (1990) Epidemiology of meniscal lesions in the knee, 1215 open operations in Copenhagen 1982-84. Acta Orthop Scand 61:435-437

34. DeHaven KE (1980) Diagnosis of acute knee injuries with hemarthrosis. Am J Sports Med 8:9-14

35. Harper KW, Helms CA, Lambert HS, Higgins LD (2005) Radial meniscal tears: significance, incidence, and MR appearance. AJR Am J Roentgenol 185:1429-1434

36. Jee WH, McCauley TR, Kim JM, Jun DJ, Lee YJ, Choi BG, Choi KH (2003) Meniscal tear configurations: categorization with MR imaging. AJR Am J Roentgenol 180:93-97

37. Magee T, Shapiro M, Williams D (2002) MR accuracy and arthroscopic incidence of meniscal radial tears. Skeletal Radiol 31:686-689

38. Metcalf MH, Barrett GR (2004) Prospective evaluation of 1485 meniscal tear patterns in patients with stable knees. Am J Sports Med 32:675-680

39. Ihara H, Miwa M, Takayanagi K, Nakayama A (1994) Acute torn meniscus combined with acute cruciate ligament injury. Second look arthroscopy after 3-month conservative treatment. Clin Orthop Relat Res 307:146-154

40. Shelbourne KD, Nitz PA (1991) The O’Donoghue triad revisited. Combined knee injuries involving anterior cruciate and medial collateral ligament tears. Am J Sports Med 19:474-477

41. Cipolla M, Scala A, Gianni E, Puddu G (1995) Different patterns of meniscal tears in acute anterior cruciate ligament (ACL) ruptures and in chronic ACL-deficient knees. Classification, staging and timing of treatment. Knee Surg Sports Traumatol Arthrosc 3:130-134

42. Daniel DM, Stone ML, Dobson BE, Fithian DC, Rossman DJ, Kaufman KR (1994) Fate of the ACL-injured patient. A prospective outcome study. Am J Sports Med 22:632-644

43. Keene GC, Bickerstaff D, Rae PJ, Paterson RS (1993) The natural history of meniscal tears in anterior cruciate ligament insufficiency. Am J Sports Med 21:672-679

44. Al Saran Y, Al Lhaidan A, Al Garni N, Al Aqeel M, Alomar A (2014) Patterns of meniscal damage associated with acute ACL rupture. J Orthop Rheumatol 2(1):4

45. Bellabarba C, Bush-Joseph CA, Bach BR (1997) Patterns of meniscal injury in the anterior cruciate-deficient knee: a review of the literature. Am J Orthop 26:18-23

46. Thompson WO, Fu FH (1993) The meniscus in the cruciatedeficient knee. Clin Sports Med 12:771-796

47. Wickiewicz TL (1990) Meniscal injuries in the cruciate-deficient knee. Clin Sports Med 9:681-694

48. Nikolić DK (1998) Lateral meniscal tears and their evolution in acute injuries of the anterior cruciate ligament of the knee. Arthroscopic analysis. Knee Surg Sports Traumatol Arthrosc $6: 26-30$

49. Gadeyne S, Besse JL, Galand-Desme S, Lerat JL, Moyen B (2006) Analysis of meniscal lesions accompanying anterior cruciate ligament tears: A retrospective analysis of 156 patients. Rev Chir Orthop Reparatrice Appar Mot 92:448-454

50. Ghodadra N, Mall NA, Karas V, Grumet RC, Kirk S, McNickle AG, Garrido CP, Cole BJ, Bach BR (2013) Articular and meniscal pathology associated with primary anterior cruciate ligament reconstruction. J Knee Surg 26:185-193 
51. Dye SF, Vaupel GL, Dye CC (1998) Conscious neurosensory mapping of the internal structures of the human knee without intraarticular anesthesia. Am J Sports Med 26:773-777

52. Torres L, Dunlop DD, Peterfy C, Guermazi A, Prasad P, Hayes KW, Song J, Cahue S, Chang A, Marshall M, Sharma L (2006) The relationship between specific tissue lesions and pain severity in persons with knee osteoarthritis. Osteoarthr Cartil 14:1033-1040

53. Grönblad M, Korkala O, Liesi P, Karaharju E (1985) Innervation of synovial membrane and meniscus. Acta Orthop Scand 56:484-486

54. Mine T, Kimura M, Sakka A, Kawai S (2000) Innervation of nociceptors in the menisci of the knee joint: an immunohistochemical study. Arch Orthop Trauma Surg 120:201-204

55. Cuellar JM, Scuderi GJ, Cuellar VG, Golish SR, Yeomans DC (2009) Diagnostic utility of cytokine biomarkers in the evaluation of acute knee pain. J Bone Joint Surg Am 91:2313-2320

56. Gobbo Rda R, Rangel Vde O, Karam FC, Pires LA (2011) Physical examination for diagnosing meniscal injuries: correlation with surgical findings. Rev Bras Ortop 46:726-729

57. Goossens P, Keijsers E, van Geenen RJ, Zijta A, van den Broek M, Verhagen AP, Scholten-Peeters GG (2015) Validity of the Thessaly test in evaluating meniscal tears compared with arthroscopy: a diagnostic accuracy study. J Orthop Sports Phys Ther 45:18-24

58. Kocabey Y, Nyland J, Isbell WM, Caborn DN (2004) Patient outcomes following T-Fix meniscal repair and a modifiable, progressive rehabilitation program, a retrospective study. Arch Orthop Trauma Surg 124:592-596

59. Mohan BR, Gosal HS (2007) Reliability of clinical diagnosis in meniscal tears. Int Orthop 31:57-60

60. Muellner T, Weinstabl R, Schabus R, Vécsei V, Kainberger F (1997) The diagnosis of meniscal tears in athletes. A comparison of clinical and magnetic resonance imaging investigations. Am J Sports Med 25:7-12

61. Rayan F, Bhonsle S, Shukla DD (2009) Clinical, MRI, and arthroscopic correlation in meniscal and anterior cruciate ligament injuries. Int Orthop 33:129-132

62. Rose NE, Gold SM (1996) A comparison of accuracy between clinical examination and magnetic resonance imaging in the diagnosis of meniscal and anterior cruciate ligament tears. Arthroscopy 12:398-405

63. Akseki D, Ozcan O, Boya H, Pinar H (2004) A new weightbearing meniscal test and a comparison with McMurray's test and joint line tenderness. Arthroscopy 20:951-958

64. Blyth M, Anthony I, Francq B, Brooksbank K, Downie P, Powell A, Jones B, MacLean A, McConnachie A, Norrie J (2015) Diagnostic accuracy of the Thessaly test, standardised clinical history and other clinical examination tests (Apley's, McMurray's and joint line tenderness) for meniscal tears in comparison with magnetic resonance imaging diagnosis. Health Technol Assess 19:1-62

65. Eren OT (2003) The accuracy of joint line tenderness by physical examination in the diagnosis of meniscal tears. Arthroscopy 19:850-854

66. Karachalios T, Hantes M, Zibis AH, Zachos V, Karantanas AH, Malizos KN (2005) Diagnostic accuracy of a new clinical test (the Thessaly test) for early detection of meniscal tears. J Bone Joint Surg Am 87:955-962

67. Konan S, Rayan F, Haddad FS (2009) Do physical diagnostic tests accurately detect meniscal tears? Knee Surg Sports Traumatol Arthrosc Germany 17:806-811

68. Kurosaka M, Yagi M, Yoshiya S, Muratsu H, Mizuno K (1999) Efficacy of the axially loaded pivot shift test for the diagnosis of a meniscal tear. Int Orthop 23:271-274
69. Beaufils P, Hulet C, Dhénain M, Nizard R, Nourissat G, Pujol $\mathrm{N}$ (2009) Clinical practice guidelines for the management of meniscal lesions and isolated lesions of the anterior cruciate ligament of the knee in adults. Orthop Traumatol Surg Res 95:437-442

70. Feller JA, Webster KE (2001) Clinical value of magnetic resonance imaging of the knee. ANZ J Surg 71:534-537

71. Jackson DW, Jennings LD, Maywood RM, Berger PE (1988) Magnetic resonance imaging of the knee. Am J Sports Med $16: 29-38$

72. Kuikka PI, Sillanpää P, Mattila VM, Niva MH, Pihlajamäki HK (2009) Magnetic resonance imaging in acute traumatic and chronic meniscal tears of the knee: a diagnostic accuracy study in young adults. Am J Sports Med 37:1003-1008

73. McNally EG (2002) Magnetic resonance imaging of the knee. BMJ 325:115-116

74. Miller GK (1996) A prospective study comparing the accuracy of the clinical diagnosis of meniscus tear with magnetic resonance imaging and its effect on clinical outcome. Arthroscopy $12: 406-413$

75. Nam TS, Kim MK, Ahn JH (2014) Efficacy of magnetic resonance imaging evaluation for meniscal tear in acute anterior cruciate ligament injuries. Arthroscopy 30:475-482

76. Timotijevic S, Vukasinovic Z, Bascarevic Z (2014) Correlation of clinical examination, ultrasound sonography, and magnetic resonance imaging findings with arthroscopic findings in relation to acute and chronic lateral meniscus injuries. J Orthop Sci 19:71-76

77. Trieshmann HW, Mosure J (1997) A comparison of accuracy between clinical examination and magnetic resonance imaging in the diagnosis of meniscal and anterior cruciate ligament tears. Arthroscopy 13:275-276

78. Van Dyck P, Vanhoenacker FM, Lambrecht V, Wouters K, Gielen JL, Dossche L, Parizel PM (2013) Prospective comparison of 1.5 and 3.0-T MRI for evaluating the knee menisci and ACL. J Bone Joint Surg Am 95:916-924

79. Dacombe PJ (2013) Shelbourne's update of the O'Donoghue knee triad in a 17-year-old male Rugby player. BMJ Case Rep. https://doi.org/10.1136/bcr.01.2012.5593

80. Ercin E, Kaya I, Sungur I, Demirbas E, Ugras AA, Cetinus EM (2012) History, clinical findings, magnetic resonance imaging, and arthroscopic correlation in meniscal lesions. Knee Surg Sports Traumatol Arthrosc 20:851-856

81. Thomas S, Pullagura M, Robinson E, Cohen A, Banaszkiewicz P (2007) The value of magnetic resonance imaging in our current management of ACL and meniscal injuries. Knee Surg Sports Traumatol Arthrosc Germany 15:533-536

82. Ben-Galim P, Steinberg EL, Amir H, Ash N, Dekel S, Arbel R (2006) Accuracy of magnetic resonance imaging of the knee and unjustified surgery. Clin Orthop Relat Res 447:100-104

83. Roßbach BP, Pietschmann MF, Gülecyüz MF, Niethammer TR, Ficklscherer A, Wild S, Jansson V, Müller PE (2014) Indications requiring preoperative magnetic resonance imaging before knee arthroscopy. Arch Med Sci 10:1147-1152

84. Ahn JH, Lee YS, Yoo JC, Chang MJ, Koh KH, Kim MH (2010) Clinical and second-look arthroscopic evaluation of repaired medial meniscus in anterior cruciate ligament-reconstructed knees. Am J Sports Med 38:472-477

85. Horibe S, Shino K, Maeda A, Nakamura N, Matsumoto N, Ochi $\mathrm{T}$ (1996) Results of isolated meniscal repair evaluated by secondlook arthroscopy. Arthroscopy 12:150-155

86. Miao Y, Yu JK, Ao YF, Zheng ZZ, Gong X, Leung KK (2011) Diagnostic values of 3 methods for evaluating meniscal healing status after meniscal repair: comparison among second-look arthroscopy, clinical assessment, and magnetic resonance imaging. Am J Sports Med 39:735-742 
87. Morgan CD, Wojtys EM, Casscells CD, Casscells SW (1991) Arthroscopic meniscal repair evaluated by second-look arthroscopy. Am J Sports Med 19:632-637

88. Tachibana Y, Sakaguchi K, Goto T, Oda H, Yamazaki K, Iida S (2010) Repair integrity evaluated by second-look arthroscopy after arthroscopic meniscal repair with the FasT-Fix during anterior cruciate ligament reconstruction. Am J Sports Med 38:965-971

89. Muellner T, Egkher A, Nikolic A, Funovics M, Metz V (1999) Open meniscal repair: clinical and magnetic resonance imaging findings after twelve years. Am J Sports Med 27:16-20

90. Pujol N, Bohu Y, Boisrenoult P, Macdes A, Beaufils P (2013) Clinical outcomes of open meniscal repair of horizontal meniscal tears in young patients. Knee Surg Sports Traumatol Arthrosc 21:1530-1533

91. Vance K, Meredick R, Schweitzer ME, Lubowitz JH (2009) Magnetic resonance imaging of the postoperative meniscus. Arthroscopy 25:522-530

92. Ciliz D, Ciliz A, Elverici E, Sakman B, Yüksel E, Akbulut O (2008) Evaluation of postoperative menisci with MR arthrography and routine conventional MRI. Clin Imaging 32:212-219

93. Magee T (2014) Accuracy of 3-Tesla MR and MR arthrography in diagnosis of meniscal retear in the post-operative knee. Skeletal Radiol 43:1057-1064

94. Vives MJ, Homesley D, Ciccotti MG, Schweitzer ME (2003) Evaluation of recurring meniscal tears with gadolinium-enhanced magnetic resonance imaging: a randomized, prospective study. Am J Sports Med 31:868-873

95. Pujol N, Panarella L, Selmi TA, Neyret P, Fithian D, Beaufils $P$ (2008) Meniscal healing after meniscal repair: a CT arthrography assessment. Am J Sports Med 36:1489-1495

96. Asahina S, Muneta T, Hoshino A, Niga S, Yamamoto H (1998) Intermediate-term results of meniscal repair in anterior cruciate ligament-reconstructed knees. Am J Sports Med 26:688-691

97. Gill SS, Diduch DR (2002) Outcomes after meniscal repair using the meniscus arrow in knees undergoing concurrent anterior cruciate ligament reconstruction. Arthroscopy 18:569-577

98. Petsche TS, Selesnick H, Rochman A (2002) Arthroscopic meniscus repair with bioabsorbable arrows. Arthroscopy 18:246-253

99. Siebold R, Dehler C, Boes L, Ellermann A (2007) Arthroscopic all-inside repair using the Meniscus Arrow: long-term clinical follow-up of 113 patients. Arthroscopy 23:394-399

100. Stone RG, Frewin PR, Gonzales S (1990) Long-term assessment of arthroscopic meniscus repair: a two- to six-year follow-up study. Arthroscopy 6:73-78

101. Asahina S, Muneta T, Yamamoto H (1996) Arthroscopic meniscal repair in conjunction with anterior cruciate ligament reconstruction: factors affecting the healing rate. Arthroscopy 12:541-545

102. Buseck MS, Noyes FR (1991) Arthroscopic evaluation of meniscal repairs after anterior cruciate ligament reconstruction and immediate motion. Am J Sports Med 19:489-494

103. Noyes FR, Barber-Westin SD (2000) Arthroscopic repair of meniscus tears extending into the avascular zone with or without anterior cruciate ligament reconstruction in patients 40 years of age and older. Arthroscopy 16:822-829

104. Noyes FR, Barber-Westin SD (2002) Arthroscopic repair of meniscal tears extending into the avascular zone in patients younger than twenty years of age. Am J Sports Med 30:589-600

105. O'Shea JJ, Shelbourne KD (2003) Repair of locked buckethandle meniscal tears in knees with chronic anterior cruciate ligament deficiency. Am J Sports Med 31:216-220

106. Rubman MH, Noyes FR, Barber-Westin SD (1998) Arthroscopic repair of meniscal tears that extend into the avascular zone.
A review of 198 single and complex tears. Am J Sports Med 26:87-95

107. Westermann RW, Wright RW, Spindler KP, Huston LJ, Wolf BR (2014) Meniscal repair with concurrent anterior cruciate ligament reconstruction: operative success and patient outcomes at 6-year follow-up. Am J Sports Med 42:2184-2192

108. Bach BR, Dennis M, Balin J, Hayden J (2005) Arthroscopic meniscal repair: analysis of treatment failures. J Knee Surg $18: 278-284$

109. Barber-Westin SD, Noyes FR (2014) Clinical healing rates of meniscus repairs of tears in the central-third (red-white) zone. Arthroscopy 30:134-146

110. Billante MJ, Diduch DR, Lunardini DJ, Treme GP, Miller MD, Hart JM (2008) Meniscal repair using an all-inside, rapidly absorbing, tensionable device. Arthroscopy 24:779-785

111. Cannon WD, Vittori JM (1992) The incidence of healing in arthroscopic meniscal repairs in anterior cruciate ligamentreconstructed knees versus stable knees. Am J Sports Med 20:176-181

112. Johnson MJ, Lucas GL, Dusek JK, Henning CE (1999) Isolated arthroscopic meniscal repair: a long-term outcome study (more than 10 years). Am J Sports Med 27:44-49

113. Kalliakmanis A, Zourntos S, Bousgas D, Nikolaou P (2008) Comparison of arthroscopic meniscal repair results using 3 different meniscal repair devices in anterior cruciate ligament reconstruction patients. Arthroscopy 24:810-816

114. Orfaly RM, McConkey JP, Regan WD (1998) The fate of meniscal tears after anterior cruciate ligament reconstruction. Clin J Sport Med 8:102-105

115. Pujol N, Barbier O, Boisrenoult P, Beaufils P (2011) Amount of meniscal resection after failed meniscal repair. Am J Sports Med 39:1648-1652

116. Quinby JS, Golish SR, Hart JA, Diduch DR (2006) All-inside meniscal repair using a new flexible, tensionable device. Am J Sports Med 34:1281-1286

117. Ryu RK, Dunbar WH (1988) Arthroscopic meniscal repair with two-year follow-up: a clinical review. Arthroscopy 4:168-173

118. Spindler KP, Huston LJ, Wright RW, Kaeding CC, Marx RG, Amendola A, Parker RD, Andrish JT, Reinke EK, Harrell FE, Dunn WR (2011) The prognosis and predictors of sports function and activity at minimum 6 years after anterior cruciate ligament reconstruction: a population cohort study. Am J Sports Med 39:348-359

119. Steenbrugge F, Van Nieuwenhuyse W, Verdonk R, Verstraete K (2005) Arthroscopic meniscus repair in the ACL-deficient knee. Int Orthop 29:109-112

120. Stone RG, VanWinkle GN (1986) Arthroscopic review of meniscal repair: assessment of healing parameters. Arthroscopy 2:77-81

121. Barrett GR, Field MH, Treacy SH, Ruff CG (1998) Clinical results of meniscus repair in patients 40 years and older. Arthroscopy 14:824-829

122. Perdue PS, Hummer CD, Colosimo AJ, Heidt RS, Dormer SG (1996) Meniscal repair: outcomes and clinical follow-up. Arthroscopy 12:694-698

123. Ding C, Martel-Pelletier J, Pelletier JP, Abram F, Raynauld JP, Cicuttini F, Jones G (2007) Meniscal tear as an osteoarthritis risk factor in a largely non-osteoarthritic cohort: a cross-sectional study. J Rheumatol 34:776-784

124. Ford GM, Hegmann KT, White GL, Holmes EB (2005) Associations of body mass index with meniscal tears. Am J Prev Med Netherlands 28:364-368

125. Laberge MA, Baum T, Virayavanich W, Nardo L, Nevitt MC, Lynch J, McCulloch CE, Link TM (2012) Obesity increases the prevalence and severity of focal knee abnormalities diagnosed 
using 3T MRI in middle-aged subjects-data from the Osteoarthritis Initiative. Skeletal Radiol 41:633-641

126. Sommerfeldt MF, Magnussen RA, Randall KL, Tompkins M, Perkins B, Sharma A, Blackwell R, Flanigan DC (2016) The Relationship between Body Mass Index and Risk of Failure following Meniscus Repair. J Knee Surg 29:645-648

127. Bizzini M, Gorelick M, Drobny T (2006) Lateral meniscus repair in a professional ice hockey goaltender: a case report with a 5-year follow-up. J Orthop Sports Phys Ther 36:89-100

128. Logan M, Watts M, Owen J, Myers P (2009) Meniscal repair in the elite athlete: results of 45 repairs with a minimum 5-year follow-up. Am J Sports Med 37:1131-1134

129. Noyes FR, Barber-Westin SD, Chen RC (2011) Repair of complex and avascular meniscal tears and meniscal transplantation. Instr Course Lect 60:415-437

130. Beaufils P, Bastos R, Wakim E, Cho SH, Petit-Jouvet C (1992) Meniscal injury in the plastic reconstruction of the anterior cruciate ligament. Meniscal suture or abstention. Rev Chir Orthop Reparatrice Appar Mot 78:285-291

131. Duchman KR, Westermann RW, Spindler KP, Reinke EK, Huston LJ, Amendola A, Wolf BR (2015) The fate of meniscus tears left in situ at the time of anterior cruciate ligament reconstruction: a 6-year follow-up study from the MOON cohort. Am J Sports Med 43:2688-2695

132. Fitzgibbons RE, Shelbourne KD (1995) "Aggressive" nontreatment of lateral meniscal tears seen during anterior cruciate ligament reconstruction. Am J Sports Med 23:156-159

133. Ichinohe $\mathrm{S}$, Yoshida $\mathrm{M}$, Murakami $\mathrm{H}$, Takayama $\mathrm{H}$, Izumiyama S, Shimamura T (2000) Meniscal tearing after ACL reconstruction. J Orthop Surg 8:53-59

134. Lee DW, Jang HW, Lee SR, Park JH, Ha JK, Kim JG (2014) Clinical, radiological, and morphological evaluations of posterior horn tears of the lateral meniscus left in situ during anterior cruciate ligament reconstruction. Am J Sports Med 42:327-335

135. Pierre A, Hulet C, Locker B, Schiltz D, Delbarre JC, Vielpeau C (2001) Outcome of 95 stable meniscal tears left in place after reconstruction of the anterior cruciate ligament. Revue de Chirurgie Orthopedique et Reparatrice de 1 Appareil Moteur 87:661-668

136. Pujol N, Beaufils P (2009) Healing results of meniscal tears left in situ during anterior cruciate ligament reconstruction: a review of clinical studies. Knee Surg Sports Traumatol Arthrosc 17:396-401

137. Rothermich MA, Cohen JA, Wright R (2016) Stable Meniscal Tears Left In Situ at the Time of Arthroscopic Anterior Cruciate Ligament Reconstruction: A Systematic Review. J Knee Surg 29:228-234

138. Shelbourne KD, Rask BP (2001) The sequelae of salvaged nondegenerative peripheral vertical medial meniscus tears with anterior cruciate ligament reconstruction. Arthroscopy 17:270-274

139. Shelbourne KD, Heinrich J (2004) The long-term evaluation of lateral meniscus tears left in situ at the time of anterior cruciate ligament reconstruction. Arthroscopy 20:346-351

140. Talley MC, Grana WA (2000) Treatment of partial meniscal tears identified during anterior cruciate ligament reconstruction with limited synovial abrasion. Arthroscopy 16:6-10

141. Vermesan D, Prejbeanu R, Laitin S, Damian G, Deleanu B, Abbinante A, Flace P, Cagiano R (2013) Arthroscopic debridement compared to intra-articular steroids in treating degenerative medial meniscal tears. Eur Rev Med Pharmacol Sci 17:3192-3196

142. Yagishita K, Muneta T, Ogiuchi T, Sekiya I, Shinomiya K (2004) Healing potential of meniscal tears without repair in knees with anterior cruciate ligament reconstruction. Am J Sports Med 32:1953-1961
143. Zemanovic JR, McAllister DR, Hame SL (2004) Nonoperative treatment of partial-thickness meniscal tears identified during anterior cruciate ligament reconstruction. Orthopedics 27:755-758

144. Lynch MA, Henning CE, Glick KR (1983) Knee joint surface changes. Long-term follow-up meniscus tear treatment in stable anterior cruciate ligament reconstructions. Clin Orthop Relat Res 172:148-153

145. Vermesan D, Prejbeanu R, Laitin S, Georgianu V, Haragus H, Nitescu S, Tatullo M, Tattoli M, Caprio M, Cagiano R (2014) Meniscal tears left in situ during anatomic single bundle anterior cruciate ligament reconstruction. Eur Rev Med Pharmacol Sci $18: 252-256$

146. Alpar EK, Bilsel N (1991) Meniscus repair. Arch Orthop Trauma Surg 110:112-113

147. Klimkiewicz JJ, Shaffer B (2002) Meniscal surgery 2002 update: indications and techniques for resection, repair, regeneration, and replacement. Arthroscopy 18:14-25

148. Persson F, Turkiewicz A, Bergkvist D, Neuman P, Englund M (2018) The risk of symptomatic knee osteoarthritis after arthroscopic meniscus repair vs partial meniscectomy vs the general population. Osteoarthr Cartil 26:195-201

149. Rath E, Richmond JC (2000) The menisci: basic science and advances in treatment. Br J Sports Med 34:252-257

150. Majewski M, Stoll R, Widmer H, Müller W, Friederich NF (2006) Midterm and long-term results after arthroscopic suture repair of isolated, longitudinal, vertical meniscal tears in stable knees. Am J Sports Med 34:1072-1076

151. Haklar U, Kocaoglu B, Nalbantoglu U, Tuzuner T, Guven O (2008) Arthroscopic repair of radial lateral meniscus [corrected] tear by double horizontal sutures with inside-outside technique. Knee 15:355-359

152. Ra HJ, Ha JK, Jang SH, Lee DW, Kim JG (2013) Arthroscopic inside-out repair of complete radial tears of the meniscus with a fibrin clot. Knee Surg Sports Traumatol Arthrosc 21:2126-2130

153. Yoo JC, Ahn JH, Lee SH, Lee SH, Kim JH (2007) Suturing complete radial tears of the lateral meniscus. Arthroscopy 23(1249):1-7

154. Brody JM, Lin HM, Hulstyn MJ, Tung GA (2006) Lateral meniscus root tear and meniscus extrusion with anterior cruciate ligament tear. Radiology 239:805-810

155. Pan F, Hua S, Ma Z (2015) Surgical treatment of combined posterior root tears of the lateral meniscus and ACL tears. Med Sci Monit 21:1345-1349

156. Shelbourne KD, Roberson TA, Gray T (2011) Long-term evaluation of posterior lateral meniscus root tears left in situ at the time of anterior cruciate ligament reconstruction. Am J Sports Med 39:1439-1443

157. Han SB, Shetty GM, Lee DH, Chae DJ, Seo SS, Wang KH, Yoo SH, Nha KW (2010) Unfavorable results of partial meniscectomy for complete posterior medial meniscus root tear with early osteoarthritis: a 5- to 8-year follow-up study. Arthroscopy 26:1326-1332

158. Kim SB, Ha JK, Lee SW, Kim DW, Shim JC, Kim JG, Lee MY (2011) Medial meniscus root tear refixation: comparison of clini$\mathrm{cal}$, radiologic, and arthroscopic findings with medial meniscectomy. Arthroscopy 27:346-354

159. Costouros JG, Raineri GR, Cannon WD (1999) Return of motion after simultaneous repair of displaced bucket-handle meniscal tears and anterior cruciate ligament reconstruction. Arthroscopy 15:192-196

160. Espejo-Reina A, Serrano-Fernández JM, Martín-Castilla B, Estades-Rubio FJ, Briggs KK, Espejo-Baena A (2014) Outcomes after repair of chronic bucket-handle tears of medial meniscus. Arthroscopy 30:492-496 
161. Shelbourne KD, Johnson GE (1993) Locked bucket-handle meniscal tears in knees with chronic anterior cruciate ligament deficiency. Am J Sports Med 21:779-782

162. Berbig R, Rillmann P (2000) Timing of the surgery of rupture of the anterior cruciate ligament. Effects of acute or delayed surgery on arthrofibrosis rate and work disability. Unfallchirurg 103:726-730

163. Mayr HO, Weig TG, Plitz W (2004) Arthrofibrosis following ACL reconstruction-reasons and outcome. Arch Orthop Trauma Surg 124:518-522

164. Shelbourne KD, Wilckens JH, Mollabashy A, DeCarlo M (1991) Arthrofibrosis in acute anterior cruciate ligament reconstruction. The effect of timing of reconstruction and rehabilitation. Am J Sports Med 19:332-336

165. DeHaven KE (1985) Rationale for meniscus repair or excision. Clin Sports Med 4:267-273

166. Granan LP, Bahr R, Lie SA, Engebretsen L (2009) Timing of anterior cruciate ligament reconstructive surgery and risk of cartilage lesions and meniscal tears: a cohort study based on the Norwegian National Knee Ligament Registry. Am J Sports Med 37:955-961

167. Kennedy J, Jackson MP, O'Kelly P, Moran R (2010) Timing of reconstruction of the anterior cruciate ligament in athletes and the incidence of secondary pathology within the knee. J Bone Joint Surg Br 92:362-366

168. Rodkey WG, DeHaven KE, Montgomery WH, Baker CL, Beck CL, Hormel SE, Steadman JR, Cole BJ, Briggs KK (2008) Comparison of the collagen meniscus implant with partial meniscectomy. A prospective randomized trial. J Bone Joint Surg Am 90:1413-1426

169. Zaffagnini S, Marcheggiani Muccioli GM, Lopomo N, Bruni D, Giordano G, Ravazzolo G, Molinari M, Marcacci M (2011) Prospective long-term outcomes of the medial collagen meniscus implant versus partial medial meniscectomy: a minimum 10-year follow-up study. Am J Sports Med 39:977-985

170. Bouyarmane H, Beaufils P, Pujol N, Bellemans J, Roberts S, Spalding T, Zaffagnini S, Marcacci M, Verdonk P, Womack M, Verdonk R (2014) Polyurethane scaffold in lateral meniscus segmental defects: clinical outcomes at 24 months follow-up. Orthop Traumatol Surg Res 100:153-157

171. De Coninck T, Huysse W, Willemot L, Verdonk R, Verstraete K, Verdonk P (2013) Two-year follow-up study on clinical and radiological outcomes of polyurethane meniscal scaffolds. Am J Sports Med 41:64-72

172. Warth RJ, Rodkey WG (2015) Resorbable collagen scaffolds for the treatment of meniscus defects: a systematic review. Arthroscopy 31:927-941

173. Hirschmann MT, Keller L, Hirschmann A, Schenk L, Berbig R, Lüthi U, Amsler F, Friederich NF, Arnold MP (2013) One-year clinical and MR imaging outcome after partial meniscal replacement in stabilized knees using a collagen meniscus implant. Knee Surg Sports Traumatol Arthrosc 21:740-747

174. Bulgheroni E, Grassi A, Bulgheroni P, Marcheggiani Muccioli GM, Zaffagnini S, Marcacci M (2015) Long-term outcomes of medial CMI implant versus partial medial meniscectomy in patients with concomitant ACL reconstruction. Knee Surg Sports Traumatol Arthrosc 23:3221-3227

175. Henning CE, Lynch MA, Clark JR (1987) Vascularity for healing of meniscus repairs. Arthroscopy 3:13-18

176. Haas AL, Schepsis AA, Hornstein J, Edgar CM (2005) Meniscal repair using the FasT-Fix all-inside meniscal repair device. Arthroscopy 21:167-175

177. Krych AJ, Pitts RT, Dajani KA, Stuart MJ, Levy BA, Dahm DL (2010) Surgical repair of meniscal tears with concomitant anterior cruciate ligament reconstruction in patients 18 years and younger. Am J Sports Med 38:976-982
178. Tenuta JJ, Arciero RA (1994) Arthroscopic evaluation of meniscal repairs. Factors that effect healing. Am. J. Sports Med 22:797-802

179. Biedert RM (2000) Treatment of intrasubstance meniscal lesions: a randomized prospective study of four different methods. Knee Surg Sports Traumatol Arthrosc 8:104-108

180. Fox JM, Rintz KG, Ferkel RD (1993) Trephination of incomplete meniscal tears. Arthroscopy 9:451-455

181. Staerke C, Kopf S, Becker R (2008) The extent of laceration of circumferential fibers with suture repair of the knee meniscus. Winner of the AGA DonJoy award 2006. Arch Orthop Trauma Surg 128:525-530

182. Ishimura M, Tamai S, Fujisawa Y (1991) Arthroscopic meniscal repair with fibrin glue. Arthroscopy 7:177-181

183. Ishimura M, Ohgushi H, Habata T, Tamai S, Fujisawa Y (1997) Arthroscopic meniscal repair using fibrin glue Part II: clinical applications. Arthroscopy 13:558-563

184. van Trommel MF, Simonian PT, Potter HG, Wickiewicz TL (1998) Different regional healing rates with the outside-in technique for meniscal repair. Am J Sports Med 26:446-452

185. Griffin JW, Hadeed MM, Werner BC, Diduch DR, Carson EW, Miller MD (2015) Platelet-rich plasma in meniscal repair: does augmentation improve surgical outcomes? Clin Orthop Relat Res 473:1665-1672

186. Becker R, Awiszus F (2001) Physiological alterations of maximal voluntary quadriceps activation by changes of knee joint angle. Muscle Nerve 24:667-672

187. Cristiani R, Rönnblad E, Engström B, Forssblad M, Stålman A (2018) Medial meniscus resection increases and medial meniscus repair preserves anterior knee laxity: a cohort study of 4497 patients with primary anterior cruciate ligament reconstruction. Am J Sports Med 46:357-362

188. Makris EA, Hadidi P, Athanasiou KA (2011) The knee meniscus: structure-function, pathophysiology, current repair techniques, and prospects for regeneration. Biomaterials 32:7411-7431

189. Svantesson E, Cristiani R, Hamrin Senorski E, Forssblad M, Samuelsson K, Stålman A (2018) Meniscal repair results in inferior short-term outcomes compared with meniscal resection: a cohort study of 6398 patients with primary anterior cruciate ligament reconstruction. Knee Surg Sports Traumatol Arthrosc 26:2251-2258

190. Feeley BT, Liu S, Garner AM, Zhang AL, Pietzsch JB (2016) The cost-effectiveness of meniscal repair versus partial meniscectomy: A model-based projection for the United States. Knee 23:674-680

191. Dean CS, Chahla J, Matheny LM, Mitchell JJ, LaPrade RF (2017) Outcomes after biologically augmented isolated meniscal repair with marrow venting are comparable with those after meniscal repair with concomitant anterior cruciate ligament reconstruction. Am J Sports Med 45:1341-1348

192. Lowery DJ, Farley TD, Wing DW, Sterett WI, Steadman JR (2006) A clinical composite score accurately detects meniscal pathology. Arthroscopy 22:1174-1179

193. Solomon DH, Simel DL, Bates DW, Katz JN, Schaffer JL (2001) The rational clinical examination. Does this patient have a torn meniscus or ligament of the knee? Value of the physical examination. JAMA 286(13):1610-1620

194. Corea JR, Moussa M, al Othman A (1994) McMurray's test tested. Knee Surg Sports Traumatol Arthrosc 2(2):70-72

195. Fowler PJ, Lubliner JA (1989) The predictive value of five clinical signs in the evaluation of meniscal pathology. Arthroscopy 5(3):184-186

196. Evans PJ, Bell GD, Frank C (1993) Prospective evaluation of the McMurray test. Am J Sports Med 21(4):604-608

197. Jackson JL, O’Malley PG, Kroenke K (2003) Evaluation of acute knee pain in primary care. Ann Intern Med 139(7):575-588 
198. Meserve BB, Cleland JA, Boucher TR (2008) A meta-analysis examining clinical test utilities for assessing meniscal injury. Clin Rehabil 22(2):143-161
Publisher's Note Springer Nature remains neutral with regard to jurisdictional claims in published maps and institutional affiliations.

\section{Affiliations}

\section{Sebastian Kopf ${ }^{1}$ (I) - Philippe Beaufils ${ }^{2}$ - Michael T. Hirschmann ${ }^{3}$ - Niccolò Rotigliano ${ }^{3} \cdot$ Matthieu Ollivier $^{4}$. Helder Pereira $^{5} \cdot$ Rene Verdonk $^{6} \cdot$ Nikica Darabos $^{7} \cdot$ Panagiotis Ntagiopoulos $^{8} \cdot$ David Dejour $^{9} \cdot$ Romain Seil $^{10,11}$. Roland Becker ${ }^{12}$}

Sebastian Kopf

s.kopf@klinikum-brandenburg.de

$\triangle$ Roland Becker

r.becker@klinikum-brandenburg.de

1 Center of Orthopaedics and Traumatology, Brandenburg Medical School Theodor Fontane, Hochstr. 29, 14770 Brandenburg an der Havel, Germany

2 Orthopaedics Department, Centre Hospitalier de Versailles, Le Chesnay, France

3 Department of Orthopaedic Surgery and Traumatology, Kantonsspital Baselland (Bruderholz, Liestal, Laufen) and University of Basel, Basel, Switzerland

4 Department of Orthopedics and Traumatology, Institute of Movement and Locomotion, St. Marguerite Hospital, 270 Boulevard Sainte Marguerite, BP 29, 13274 Marseille, France

5 Orthopedic Department Centro Hospitalar Póvoa de Varzim, Vila do Conde and ICVS/3 Bs Associated Laboratory, Minho University, Braga, Portugal
6 Department of Orthopaedic Surgery and Traumatology, University Hospital Erasmus Bruxelles, Bruxelles, Belgium

7 Department of Traumatology, Bone and Joint Surgery, Clinic of Surgery, University Hospital Centre Zagreb, Zagreb, Croatia

8 Hip and Knee Unit, Mediterraneo Hospital, 10 Ilias Street, 16675 Glyfada, Athens, Greece

9 Orthopaedic Department, Lyon-Ortho-Clinic, Clinique de La Sauvegarde, Avenue Ben Gourion, 69009 Lyon, France

10 Service de Chirurgie Orthopédique, Centre Hospitalier de Luxembourg-Clinique d' Eich, 78, 1460 Rue d' Eich, Luxembourg

11 Luxembourg Institute of Health, 78, 1460 Rue d'Eich, Luxembourg

12 Department of Orthopedics and Traumatology, Centre of Joint Replacement, Hospital Brandenburg, Medical School "Theodor Fontane", Hochstrasse 29, 14770 Brandenburg/Havel, Germany 